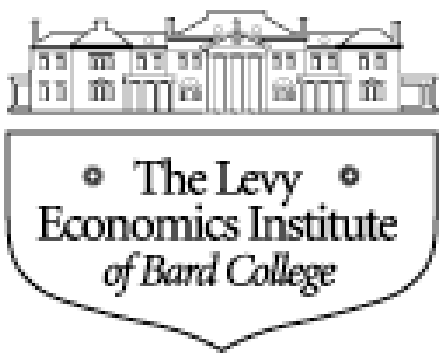

Working Paper No. 414

\title{
Household Wealth Distribution in Italy in the 1990s
}

\author{
by \\ Andrea Brandolini, * Luigi Cannari, * \\ Giovanni D'Alessio, ${ }^{*}$ and Ivan Faiella* \\ October 2004 \\ *Bank of Italy, Economic Research Department
}

The Levy Economics Institute Working Paper Collection presents research in progress by

Levy Institute scholars and conference participants. The purpose of the series is to disseminate ideas to and elicit comments from academics and professionals.

The Levy Economics Institute of Bard College, founded in 1986, is a nonprofit, nonpartisan, independently funded research organization devoted to public service. Through scholarship and economic research it generates viable, effective public policy responses to important economic problems that profoundly affect the quality of life in the United States and abroad.

The Levy Economics Institute P.O. Box 5000

Annandale-on-Hudson, NY 12504-5000

http://www.levy.org

Copyright (C) The Levy Economics Institute 2004 All rights reserved. 


\section{ABSTRACT}

This paper describes the composition and distribution of household wealth in Italy. First, the evolution of household portfolios over the last 40 years is described on the basis of newly reconstructed aggregate balance sheets. Second, the characteristics and quality of the main statistical source on wealth distribution, the Bank of Italy's Survey of Household Income and Wealth, are examined together with the statistical procedures used to adjust for nonresponse, nonreporting and underreporting. The distribution of household net worth is then studied using both adjusted and unadjusted data. Wealth inequality is found to have risen steadily during the 1990s. The increased concentration of financial wealth was an important factor in determining this path.

JEL classification: D31

Keywords: household wealth, wealth inequality, Italy 


\section{CONTENTS}

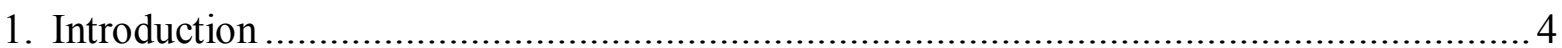

2. The composition of household net worth in macro estimates ...................................... 6

3. The Bank of Italy's Survey of Household Income and Wealth .....................................

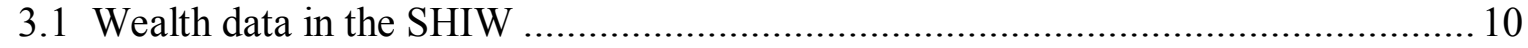

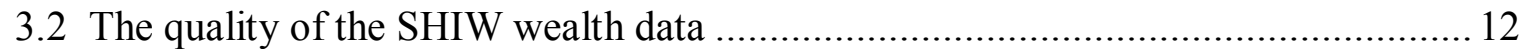

3.3 Corrections for nonresponses, nonreporting and underreporting .......................... 16

4. Microeconomic evidence on household net worth ................................................... 20



5.1 Decomposition of inequality by wealth components ........................................29

5.2 Decomposition of inequality by population subgroups …................................... 31

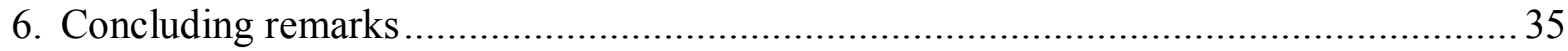

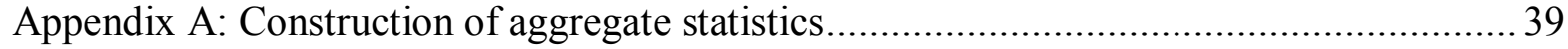

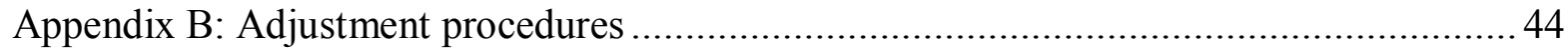

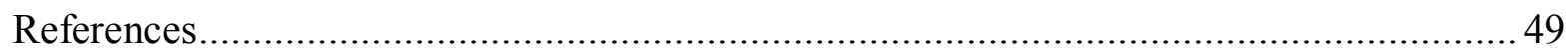




\section{INTRODUCTION ${ }^{1}$}

Like other major economies, in the second half of the 1990s Italy recorded an exceptional rise in share prices, which came after a decade of oscillations around a flattened trend (Figure 1). In March 2000 the MIB index peaked at 3.2 times the value it had recorded at the end of 1996. Following this buoyant performance, in December 2000 the value of company shares and mutual funds held by Italian households exceeded 1,000 billion euros, or 40 percent of their financial assets. Within the next two years, however, share prices fell abruptly. The MIB index lost two fifths of its value, and holdings of risky assets in households' portfolios decreased to 640 billion euros.

\section{Figure 1}

\section{SHARE AND HOUSING PRICES IN ITALY}

(index, average in $1987=100$ )

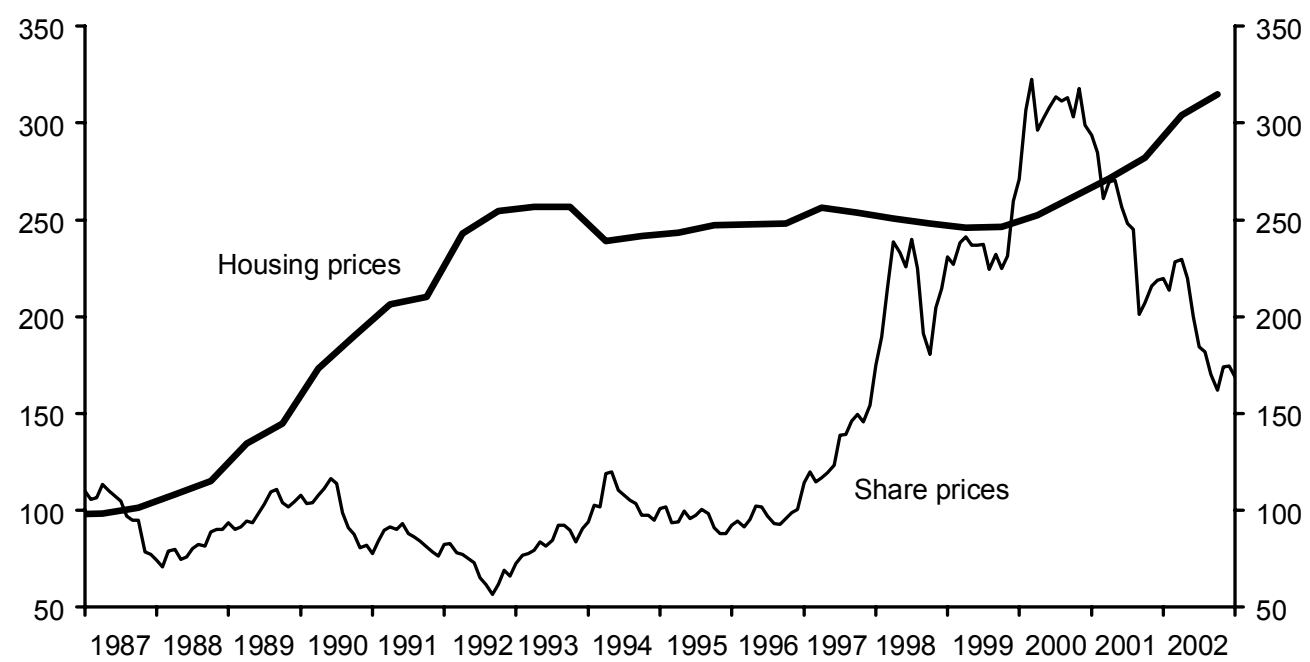

Source: Share prices: monthly averages of the MIB index from the Bank of Italy database. Housing prices: semi-annual series of the average price per square meter of new houses as estimated by Muzzicato, Sabbatini and Zollino (2002).

\footnotetext{
${ }^{1}$ This paper is dedicated to the memory of professor Albert Ando. We are indebted for very helpful comments to Riccardo De Bonis, Anders Klevmarken, Andrea Generale, Marco Magnani, Monica Paiella, Francesco Paternò, Luigi Federico Signorini and Jay Zagorsky and participants in the 27th General Conference of the International Association for Research in Income and Wealth (Djurhamn, Sweden, August 2002) and in the Conference on "International Perspectives on Household Wealth" at The Levy Economics Institute (Annandale-on-Hudson, New York, United States, October 2003). In estimating aggregate statistics we greatly benefited from the help and advice of Salvatore Muzzicato for tangible assets and Massimo Coletta for financial statistics. Christine Stone provided valuable editorial assistance. The views expressed herein are those of the authors and do not necessarily reflect those of the Bank of Italy.
} 
Housing prices have moved differently. They more than doubled between 1987 and 1993. After a short-lived reduction, they exhibited little variation until mid-2000, when they reverted to a new phase of steep growth. These wide changes in relative asset prices may be assumed to have had considerable influence on the distribution of household wealth. Were the gains from the stock market boom of the late 1990s spread across many families, or were they concentrated in the hands of few investors? What about the subsequent sharp contraction? What are the distributive implications of variations in housing prices?

In this paper we address these questions by investigating the distribution of wealth among Italian households and its evolution from 1989 to 2000. A major difficulty we have to cope with is the quality of available data. However uninformative on distributive aspects, the aggregate balance sheets of the household sector would provide a natural starting point. Unfortunately, despite a centennial research tradition, ${ }^{2}$ there are no estimates, official or unofficial, of the aggregate wealth of Italian households. Financial Accounts have been published by the Bank of Italy since the early 1960s, albeit with discontinuities; tangible assets were only estimated in few occasional studies (e.g. Tresoldi and Visco, 1975; Banca d'Italia, 1986; Marotta, 1988; Pagliano and Rossi, 1992). Microeconomic evidence is also sparse. Micro-level data on family holdings of real and financial assets have been gathered since the late 1960s in the Bank of Italy's Survey of Household Income and Wealth (SHIW), but the complete balance sheet of respondents has only been collected starting with the 1987 wave. As argued below, this information is not without flaws. However, it has been widely used to study the economic behavior of Italian households, an example being the volume edited by Ando, Guiso and Visco (1994). It was the basis for the few recent studies on wealth distribution in Italy (e.g. Cannari and D’Alessio, 1994; Jappelli and Pistaferri, 2000).

In this paper we devote considerable effort to dealing with statistical issues, in order to remedy the deficiencies of our sources. First, we assemble our own estimates of the balance sheets of consumer households. ${ }^{3}$ This evidence allows us not only to provide a benchmark for microeconomic figures, but also to show how households' portfolios have changed over the last four decades. Second, we implement several procedures to correct the SHIW microdata for nonresponse, nonreporting, and underreporting, and we present results for

\footnotetext{
${ }^{2}$ Investigations were spurred by Pantaleoni's (1890) attempt to estimate the private wealth of Italy from information on estate duties. Alternative estimates were subsequently derived by direct inventory of assets and liabilities. Zamagni (1980) briefly reviews this literature and assembles the figures for the period 1874-1938. Goldsmith and Zecchini (1999) reconstruct the balance sheets for selected years between 1861 and 1973.

${ }^{3}$ They draw on work conducted by one of the authors (AB) in collaboration with Salvatore Muzzicato.
} 
adjusted and unadjusted data alike. The consideration of both sets of results helps to verify the robustness of our conclusions.

The paper is organized as follows. Section 2 describes the composition of households' portfolios according to aggregate data (details regarding their estimation are provided in Appendix A). The characteristics and quality of the SHIW microeconomic data are examined in Section 3. This section also illustrates the adjustment procedures, more precisely described in Appendix B, and their impact. Section 4 reports microeconomic figures on household wealth and its relation to age, work status, and region of residence. Wealth inequality is studied in Section 5. Section 6 concludes. Our main findings are that inequality of household net worth rose steadily during the 1990s and that it was especially the increased concentration of financial wealth that determined such a path.

\section{THE COMPOSITION OF HOUSEHOLD NET WORTH IN MACRO ESTIMATES}

In Italian macroeconomic statistics the "household sector" has been typically broken down into the two sub-sectors "sole proprietorships" and "consumer households," purporting to separate the productive activity of small businesses from the accounts of households as consumption units. Here we follow this tradition by concentrating on consumer households. We describe in Appendix A the methods we used to estimate their balance sheets from two main sources, the Financial Accounts and the National Accounts (hence the label FANA used throughout the paper). It is important to bear in mind that there are important discontinuities which only in some cases we were able to remedy. Our estimates are therefore to be taken with caution. They are meant to offer a broad view of the evolution of Italian households' wealth in the last forty years as well as to provide an aggregate benchmark for the subsequent analysis based on individual data.

Household wealth is defined as the total market value of dwellings, consumer durable goods and financial assets, net of debts. Equities include unlisted shares and noncorporate equities, but not the value of small unincorporated businesses. The values of life insurance and private pension funds, and public pension rights are also not included. We estimate that the net worth of Italian households amounted to 6,100 billion euros at the end of $2000{ }^{4}$ or 5.2 times the gross domestic product. In 1965 the same ratio was 2.5. On the whole, between

\footnotetext{
${ }^{4}$ All money values are reported in the paper in euros, using the irreversible parity of 1,936.27 Italian lire to 1 euro. The terms "wealth" and "net worth" are used interchangeably throughout the paper.
} 
1965 and 2000 household wealth went up by 5.8 percent per year in real terms, i.e. after deflating by the consumer price index in December of each year. Real net worth per capita increased by an average 5.5 percent each year, from 16,400 to 105,400 euros at 2000 prices.

The largest part of household net worth is made up of dwellings. In the last forty years, their share in total wealth has fluctuated between 51 and 66 percent (Figure 2, top panel). The stock of durable goods has gradually declined from 16 to less than 9 percent of total net worth. The weight of tangible assets as a whole has shown a modest tendency to fall, to the benefit of financial assets: fitting a linear trend, the share of financial assets appears to have grown by about 1 percentage point every ten years. Lastly, financial liabilities have remained low for most of the period: they accounted for about 2 percent of net worth until the mid1990s. They subsequently increased to 3.6 percent in 2002.

Important reallocations of households' portfolios towards financial assets took place during the last two economic expansions. The share of financial assets rose from 26 to 38 percent between 1982 and 1989, and from 34 to 43 between 1995 and 2000. The first increase was mainly associated with the spread of direct ownership of government bonds and Treasury bills: from below 2 percent up to 1977, their share grew to 4 percent in 1982 and to a peak of 11 percent in 1988; it then gradually diminished and has held steady at around 3 percent since 1999 (Figure 2, mid panel). The second shift was instead driven by equities and mutual funds (Figure 2, bottom panel). The importance of equities in households' portfolios was already rising in the mid-1980s, but stock holdings doubled from 5 to 10 percent of net worth between 1995 and 2000, in parallel with the stock market boom and the rapid privatization of state-owned corporations and public utilities. Over the same five years, the proportion of household wealth held in mutual funds rose from 1 to 7 percent. In both episodes, however, the portfolio reallocations were not lasting, as they were followed by a quick, if incomplete, return to previous allocation between tangible and financial assets. The diversification into government bonds in the 1980s, and equities and mutual funds in the 1990s, had more permanent effects on the composition of the financial portfolio, since it overlapped with the long-run decline in the share of transaction and savings accounts in net worth, from 19 percent in the late 1970s to below 10 in 2000-02. 
Figure 2

\section{COMPOSITION OF HOUSEHOLD NET WORTH}

(percentage shares of net worth)
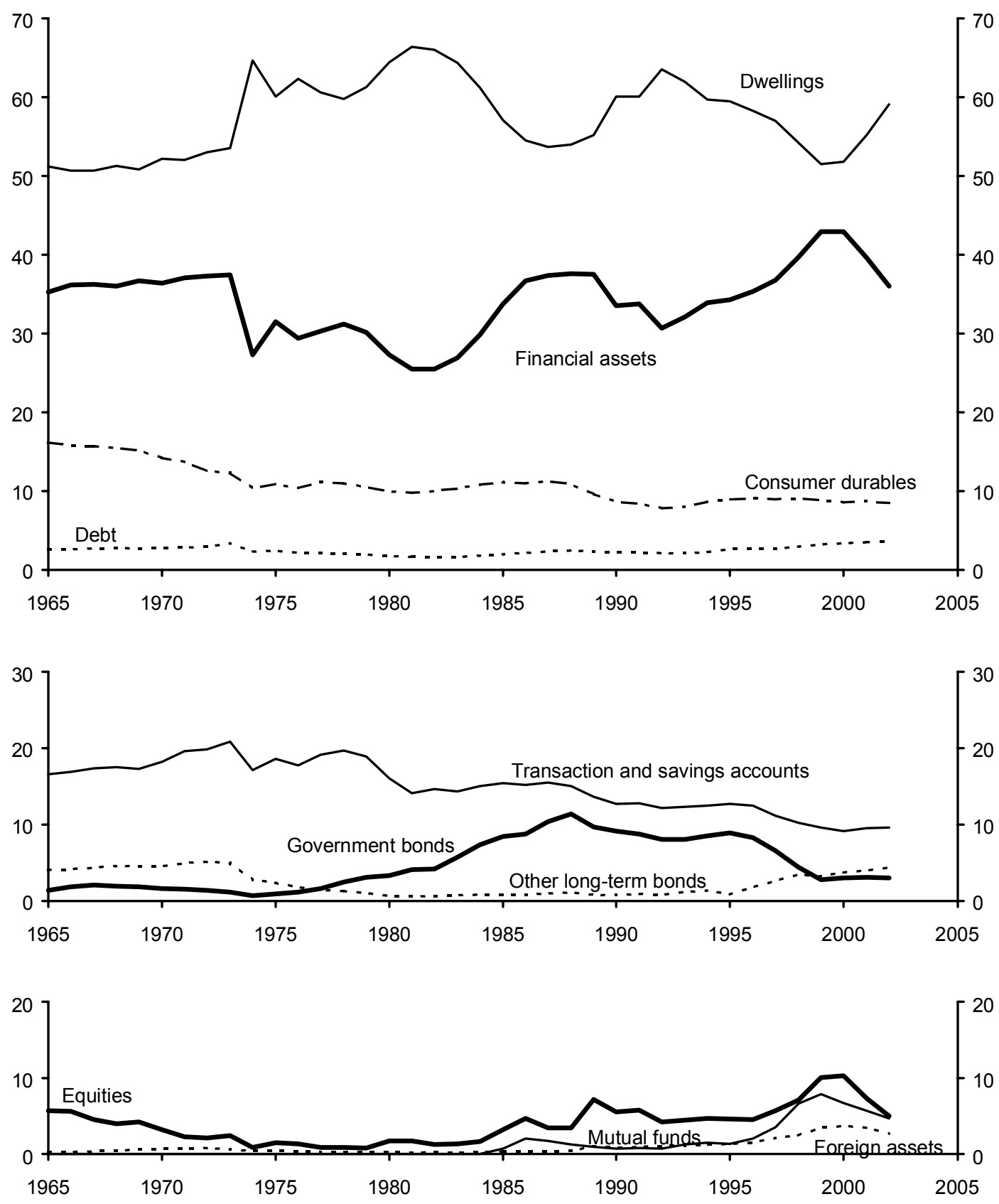

Source: See Appendix A.

As a result of the recent evolution, "in 1998 the portfolio of Italian households was much more strongly tilted toward risky assets than it had ever been in the past" (Guiso and Jappelli, 2002, p. 253). Despite these changes, the wealth composition of Italian households stands out in an international perspective for the high shares of tangible assets and cash and transactions accounts, for the low diffusion of life insurance and pension funds, and for the very modest level of indebtedness (e.g. Paiella, 2004; Magri, 2002; Faiella and Neri, 2004). 
Supply-side factors have traditionally played an important role. In the early 1990s Guiso, Jappelli and Terlizzese (1994, p. 23) remarked that: "regulations, high downpayments for the purchase of durables and housing, wide interest rate spreads and limited competition make it considerably more difficult to obtain access to credit and insurance in Italy than in almost all other industrialized countries of comparable level of development." This situation changed in the following years, when increased competition among financial intermediaries lowered entry costs, stimulated the diversification of assets and eased the access to credit, and the extensive privatization of state-owned companies helped the growth of the stock market (Guiso and Jappelli, 2002; Casolaro, Gambacorta and Gobbi, 2004). Other factors contribute. The prominence of residential housing in household portfolios reveals a strong preference for owner-occupation, which is only in part attributable to the imperfections of the rental market and the presence of borrowing constraints (Di Addario, 2002; Paiella, 2002). ${ }^{5}$ The low level of consumer credit may reflect the smaller share of large retailers in commercial distribution than in other countries (Casolaro, Gambacorta and Guiso, 2004).

\section{THE BANK OF ITALY'S SURVEY OF HOUSEHOLD INCOME AND WEALTH}

The main source of information on household wealth at the micro level is the Survey of Household Income and Wealth (SHIW), conducted by the Bank of Italy yearly from 1965 to 1987 (except for 1985), every other year until 1995 and then in 1998 and 2000 (the reference is to the year for which, not in which, the survey is conducted). The SHIW gathers information on household microeconomic behavior. Detailed data have been collected continually on the social and demographic characteristics of household members, their incomes and, since 1980, their consumption expenditure. Estimates of households' tangible assets are also available from the outset, whereas financial assets have been surveyed irregularly. The latter have been recorded on a regular basis since 1987, although their comparability over time is lessened by changes in the format of the questions. Records used in this paper relate to $1989,1991,1993,1995,1998$ and 2000 and are drawn from the Historical Archive (HA) of the survey (Version 2.1, released in January 2003).

The sample size is about 8,000 units per year. The basic survey unit is the "household," defined as a group of individuals linked by ties of blood, marriage or affection,

\footnotetext{
${ }^{5}$ Borrowing constraints are correlated with the effectiveness of judicial procedures to recover the collateral of defaulting borrowers. In regions where such procedures are more efficient, the probability of rationing is found to be lower (e.g. Guiso and Jappelli, 1991; Magri, 2002; Fabbri and Padula, 2004).
} 
sharing the same dwelling and pooling all or part of their incomes. Institutional population is not included. Data are collected in personal interviews conducted by professionally-trained interviewers. Participation is voluntary and not remunerated. As a result, nonresponse is high. In the last six waves the response rate, net of units not found at the available address, ranged between a minimum 43.3 percent in 2000 and a maximum 72.0 percent in 1993 . Thus, not only the level but also the variability of the response rate is a matter of some concern. It must be observed, however, that item nonresponse is relatively small, since interviewers are not paid for the questionnaires where answers to the main questions, among which wealth holdings, are missing. ${ }^{6}$ Further methodological details on the SHIW are given in Banca d'Italia (2000, 2002a), Brandolini and Cannari (1994) and Brandolini (1999).

\subsection{Wealth Data In The SHIW}

We define household net worth from the SHIW as the total value of tangible assets (consumer durable goods, jewelry and other valuables, real estate, businesses) and financial assets (transaction and savings accounts, government bonds, equities and other assets), net of financial liabilities (mortgages and other debts). We do not include cash and currency, severance pay (trattamento di fine rapporto), social security wealth, and the cash values of life insurance and private retirement accounts because they are not recorded in the survey. ${ }^{7}$ On the other hand, we include valuables and businesses which were not accounted for in aggregate estimates. Note that businesses cover firms, both incorporated and unincorporated, where respondents do some work. We stick to the standard practice of considering these businesses to be tangible assets because their value is closely linked to the work of the proprietors, while company shares held simply as a form of saving are classified among financial assets. Wealth components are recorded in the SHIW as follows.

\footnotetext{
${ }^{6}$ Non-response is a problem common to all sample surveys on household wealth, though it appears to be somewhat more pronounced in the SHIW. Kennickell, Starr-McCluer and Surette (2000, p. 28) report that in the Federal Reserve Board's Survey of Consumer Finances in both 1995 and 1998 the response rate was about 70 percent in the basic sample and 35 percent in the special section oversampling the very rich; it fell to 10 percent among the (likely) wealthiest families. In the wealth survey of Statistics Finland the response rates were 72.5 percent in 1987, 75.2 in 1994 and 64.9 in 1998 (Jäntti, 2002, Table 1, p. 6). In the Swedish household panel survey, Klevmarken (2001, p. 4) notices that the share of imputed items increased from little less than 20 percent in the 1980 s to about 30 percent in 1998.

${ }^{7}$ In 2000 the proportions of Italian households holding life insurance and private pensions were 20 and 12 percent, respectively. Imputing cash values on the SHIW information, Jappelli and Pistaferri (2000) estimate that in 1995 life insurance accounted for 10 percent of household financial wealth (as defined in their paper) and private pension funds for 4 percent; the corresponding figures in 1989 were 5 and 2 percent.
} 
- Consumer durable goods, jewelry and other valuables. Respondents are asked to provide their best estimate of the monetary value at the end of the year preceding the interview for three categories of durable goods: precious objects (jewelry, old and gold coins, works of art, antiques), means of transport (cars, motorbikes, caravans, boats, bicycles) and furniture, furnishing, household appliances and sundry articles.

- Real estate. Dwellings, non-residential buildings and land are subjectively evaluated by respondents. For instance, all interviewees are asked the following question: "In your opinion, what price could you ask for the dwelling in which you live (if sold unoccupied)? In other words, how much is it worth (including any cellar, garage or attic)?" For homeowners, the answer provides the value of their principal residence. ${ }^{8}$ Similar questions are asked for every piece of real estate, considered separately, possessed by the household at the end of the previous year.

- Businesses. The valuation of businesses is particularly delicate, since in Italy the percentage of self-employed labor force is among the highest in OECD countries. The SHIW adopts two methods. Members of the professions, sole proprietors, freelancers, and members of family businesses are asked how much their firm would be worth should they sell it. This value must include any equipment used, stocks, and goodwill and must exclude the value of buildings and land. Active shareholders and partners in incorporated firms are asked to indicate the market value, at the end of the previous year, of their own share in the firm. These values are those underlying our figures. ${ }^{9}$

\footnotetext{
${ }^{8}$ For recently built or renovated houses, prices per square meter implicit in the SHIW evaluations can be compared with the corresponding market prices as recorded in a survey of actual sales conducted among estate agents (see Muzzicato, Sabbatini and Zollino, 2002, for details on this source). On average, the SHIW subjectively-perceived prices underestimate actual prices by 10 to 20 percent. However, the comparison is not entirely homogeneous: actual prices refer to houses that were never occupied, whereas the SHIW evaluates mostly occupied houses. The SHIW and actual prices fall roughly in line when the latter are reduced by the discount factors reported in estate agent publications to allow for earlier occupation.

${ }^{9}$ Alternatively, using the SHIW data, family businesses and firms of professionals, freelancers, and sole proprietors could be valued as expected proceeds from selling the activity plus the value of buildings and land used in the activity plus net trade credits less activity-related debts. With this definition, the household wealth total would not change, but its composition would be affected by the reclassification of some items: the value of buildings and land would be subtracted from other real estate, trade credits toward customers from financial assets, and debts and trade debits to suppliers from liabilities. This alternative definition is probably more consistent with the recommendations of the new system of national accounts: "A balance sheet is also needed for the quasi-corporation showing the value of its fixed assets-land, buildings, machinery and equipment, inventories - used in production and also the financial assets and liabilities - owned or incurred in the name of the enterprise - bank deposits, overdrafts, trade credit and debits, other receivables or payables, etc. It is assumed that the owner's net equity in a quasi-corporation is equal to the difference between the value of its assets and the value of its other liabilities so that the net worth of the quasi-corporation is always zero in practice" (Inter-Secretariat Working Group on National Accounts, 1993, p. 94).
} 
- Financial assets. The range of financial assets listed in the questionnaire expanded over the years, mostly driven by financial innovation and portfolio diversification. In the last wave, 25 different categories were specified. Moreover, the formulation of the questions varied over the years. In 1989, amounts were inferred indirectly by asking respondents the percentage composition of their household's total wealth together with the amount held in checking accounts. In subsequent surveys, respondents were asked to choose among 15 brackets the one corresponding to the amount held of each asset. In 1998 and 2000 they were also asked for point estimates. Whenever missing, we approximate the point estimate with the mid-point of the interval. We also include among financial assets credits vis-à-vis relatives or friends not living in the house and the trade credits towards customers of professionals, freelancers, sole proprietors and family businesses. All values refer to the end of the previous year.

- Debts. Outstanding debts at the end of the year preceding the interview are recorded in the same manner since 1987. They include: debts serving to meet needs of the household, distinguished by type of purchase (buildings and restructuring, jewelry, motor vehicles, furniture and electrical appliances, and non-durable goods such as holidays); debts vis-àvis relatives or friends not living in the house; debts connected with the business activity and the trade credits of suppliers for professionals, freelancers, sole proprietors and family businesses.

All wealth components are basically valued on a "realization" basis, or "the value obtained in a sale on the open market at the date in question" (see Atkinson and Harrison, 1978, pp. 5-6 for this definition and a discussion of valuation criteria). On the other hand, the calculation of total household wealth suffers from an inconsistency due to the format of the questions: real estate and unincorporated businesses are estimated at the time of the interview, whereas all other wealth components are valued at the end of the previous year. We do not correct for this inconsistency.

We take the household as the unit of observation. (In the SHIW individual ownership is known for real estate only.) The distributions of total wealth and its main components are computed by weighting each household by either the original or the adjusted sample weights (see below), without making any allowance for the household size or composition.

\subsection{The Quality Of The SHIW Wealth Data}

Comparisons with external sources, such as the national accounts, show that the quality of income and expenditure estimates in the SHIW is comparable to that of similar 
surveys in other countries: for instance, underestimation of disposable income is valued at around 30 percent (Brandolini, 1999; see also Cannari and Violi, 1995). Data on wealth, on the other hand, are typically less reliable and their accuracy tends to vary across different assets, misreporting being lower for tangible assets than financial assets.

The Census provides a useful benchmark to assess the coverage of houses in 1991. According to the SHIW, the total number of dwellings owned by households (inclusive of those occupied under a redemption agreement or in usufruct) is 16.9 million, about a quarter less than in the Census (Table 1). The number of houses occupied by their owners slightly exceeds that recorded in the Census, but this overrepresentation disappears after adjusting for nonresponse as discussed below. While respondents are ready to disclose the ownership of the house where they live, it appears that they are far more hesitant to unveil other possessions: less than 40 percent of the dwellings which are not occupied by the owners are reported among the SHIW assets, ${ }^{10}$ even after adjusting for nonresponse.

\section{Table 1}

\section{OWNERSHIP OF DWELLINGS IN 1991}

(thousands and percent)

\begin{tabular}{|c|c|c|c|c|c|c|c|}
\hline \multirow[t]{2}{*}{ Condition of dwellings } & \multirow[t]{2}{*}{$\begin{array}{l}\text { Census } \\
\text { Number }\end{array}$} & \multicolumn{2}{|c|}{ SHIW unadjusted } & \multicolumn{2}{|c|}{$\begin{array}{l}\text { SHIW adjusted for } \\
\text { nonresponse }\end{array}$} & \multicolumn{2}{|c|}{$\begin{array}{l}\text { SHIW adjusted for } \\
\text { nonresponse and } \\
\text { nonreporting of } \\
\text { dwellings not } \\
\text { occupied by owners }\end{array}$} \\
\hline & & Number & $\begin{array}{l}\text { Reporting } \\
\text { rate }\end{array}$ & Number & $\begin{array}{l}\text { Reporting } \\
\text { rate }\end{array}$ & Number & $\begin{array}{l}\text { Reporting } \\
\text { rate }\end{array}$ \\
\hline Occupied & 17,757 & 15,171 & 85.4 & 14,960 & 84.2 & - & - \\
\hline Owner-occupied (1) & 13,419 & 13,745 & 102.4 & 13,393 & 99.8 & 13,393 & 99.8 \\
\hline Rented (2) & 3,500 & 914 & 26.1 & 1,028 & 29.4 & - & - \\
\hline Other use & 838 & 512 & 61.1 & 539 & 64.3 & - & - \\
\hline Unoccupied & 4,571 & 1,776 & 38.8 & 1,843 & 40.3 & - & - \\
\hline Holiday homes (3) & - & 1,378 & - & 1,441 & - & - & - \\
\hline Vacant or other use (4) & - & 397 & - & 401 & - & - & - \\
\hline Total & 22,328 & 16,947 & 75.9 & 16,802 & 75.3 & 22,940 & 102.7 \\
\hline of which: not owner-occupied & 8,909 & 3,202 & 35.9 & 3,409 & 38.3 & 9,547 & 107.2 \\
\hline
\end{tabular}

Source: our calculations on data from the SHIW-HA (Version 2.1) and Istat (1995), Table 2.17, p. 96, Table 4.62, p. 453, Table 4.69, p. 461. (1) Include dwellings occupied under a redemption agreement or in usufruct. (2) Dwellings rented all year to persons, households, firms and organizations. (3) Include dwellings rented part of the year to persons and households. (4) Include dwellings used for family business activity, rented part of the year to firms and organizations, and other unclassified dwellings.

\footnotetext{
${ }^{10}$ As noted earlier by Cannari and D'Alessio (1990), estimating the number of rented dwellings owned by households from tenants' rather than owners' answers gives values much closer to the Census figures (3.2 million in 1991).
} 
The SHIW total value of real estate falls short of the FANA aggregate by a proportion varying between 34 percent in 1993 and 15 percent in 2000 (Table 2, top panel). (Since the FANA aggregates include only dwellings while the SHIW figures also cover land and nonresidential buildings, the comparison understates the shortfall.) The evaluation for durable goods is about two thirds of the aggregate figure in the 1990s. Taking tangible assets as a whole, in the six waves considered the average discrepancy between the SHIW estimate and the corresponding FANA figure is 26 percent. Problems are greater for financial assets. Transaction and savings accounts appear to be underestimated in the SHIW by an average of 64 percent, government bonds by 70 percent, and private bonds, company shares and investment shares by 85 percent; worryingly, the underestimation varies considerably from one year to the other (see also Cannari et al., 1990; Cannari and D’Alessio, 1994).

Table 2

HOUSEHOLD NET WORTH: REPORTING RATE IN THE SHIW

(percentage ratios to FANA figures)

\begin{tabular}{|c|c|c|c|c|c|c|c|c|c|c|}
\hline Year & $\begin{array}{l}\text { Total } \\
\text { tangible } \\
\text { assets }\end{array}$ & $\begin{array}{l}\text { Con- } \\
\text { sumer } \\
\text { durables }\end{array}$ & $\begin{array}{l}\text { Real } \\
\text { estate }\end{array}$ & $\begin{array}{l}\text { Total } \\
\text { financial } \\
\text { assets }\end{array}$ & $\begin{array}{l}\text { Transac- } \\
\text { tion and } \\
\text { savings } \\
\text { accounts }\end{array}$ & $\begin{array}{l}\text { Govern- } \\
\text { ment } \\
\text { bonds }\end{array}$ & $\begin{array}{l}\text { Private } \\
\text { bonds, } \\
\text { equities, } \\
\text { mutual } \\
\text { funds }\end{array}$ & $\begin{array}{l}\text { Gross } \\
\text { wealth }\end{array}$ & Debt & Net worth \\
\hline & \multicolumn{10}{|c|}{ SHIW: unadjusted } \\
\hline 1989 & 75 & 85 & 73 & 26 & 39 & 26 & 9 & 58 & 34 & 59 \\
\hline 1991 & 67 & 68 & 67 & 21 & 28 & 23 & 10 & 53 & 46 & 54 \\
\hline 1993 & 66 & 62 & 66 & 24 & 26 & 27 & 19 & 54 & 57 & 54 \\
\hline 1995 & 75 & 62 & 77 & 25 & 26 & 30 & 17 & 60 & 47 & 60 \\
\hline 1998 & 81 & 67 & 84 & 28 & 46 & 26 & 19 & 63 & 37 & 63 \\
\hline 2000 & 83 & 67 & 85 & 27 & 51 & 46 & 15 & 62 & 36 & 62 \\
\hline \multirow[t]{2}{*}{ Mean } & 74 & 69 & 75 & 25 & 36 & 30 & 15 & 58 & 43 & 59 \\
\hline & \multicolumn{10}{|c|}{ SHIW: adjusted for nonresponse, nonreporting and underreporting } \\
\hline 1989 & 105 & 87 & 108 & 59 & 77 & 67 & 27 & 89 & 34 & 91 \\
\hline 1991 & 87 & 69 & 89 & 49 & 49 & 66 & 32 & 75 & 47 & 76 \\
\hline 1993 & 81 & 63 & 84 & 52 & 44 & 72 & 47 & 73 & 57 & 73 \\
\hline 1995 & 88 & 64 & 92 & 57 & 46 & 75 & 56 & 79 & 48 & 80 \\
\hline 1998 & 96 & 70 & 100 & 75 & 89 & 88 & 65 & 89 & 38 & 90 \\
\hline 2000 & 97 & 69 & 101 & 72 & 114 & 152 & 47 & 87 & 38 & 89 \\
\hline Mean & 92 & 70 & 96 & 61 & 70 & 87 & 46 & 82 & 44 & 83 \\
\hline
\end{tabular}

Source: our calculations on data from the SHIW-HA (Version 2.1) and other sources as described in Appendix A.

Several reasons can account for the differences between aggregate and survey figures.

- Survey data are well known to suffer from a tendency of interviewees to underreport, consciously or not, their wealth. The adjustments for these nonsampling errors explained in the next section allow us to reduce substantially these discrepancies. A further problem for survey-based wealth estimates stems from the high concentration of wealth and the low probability of including the wealthiest households in the sample. Our 
adjustments can do little to correct for this underrepresentation. In the U.S. Survey of Consumer Finances and in the Canadian Survey of Financial Security, this problem is addressed in the survey design through the oversampling of high-income households. (But the oversampling of families of senior white-collar employees, businessmen and professionals in the SHIW for 1987 gave unsatisfactory results; see Brandolini and Cannari, 1994, p. 381.)

- The aggregate figures themselves rest on many measurement hypotheses - as manifest in Appendix A-and are subject to errors and revisions. For instance, in the last methodological revision of the Financial Accounts the value of equities held by households in 1995 was lowered by over 30 percent, in part owing to the use of a more comprehensive source on the balance sheets of unlisted companies (see Banca d'Italia, $2002 \mathrm{~b}$, p. 50). The aggregate financial balance sheet is especially uncertain for the household sector, whose holdings are often calculated "residually" by deducting from the total the holdings of all other institutional sectors.

- Differences in sector boundaries and variable definitions prevent data from being fully comparable. Although we were able to separate out financial assets and liabilities of small unincorporated businesses, still the financial statistics include non-profit organizations and institutional population, which are not covered by the SHIW. Moreover, the SHIW respondents may employ valuation criteria which differ from those underlying aggregate statistics: they might fail to include the interest on deposits accrued in the year but not yet paid; they rate durable goods at their price in the second-hand market, or perhaps at their historical cost, whereas national accounts apply substitution prices to the real stock of durable goods computed with the perpetual inventory method; they value their house at a subjectively-perceived realization price while national accounts would use actual market prices; and so forth.

To sum up, there are large differences between the estimates of household net worth obtained from aggregate sources, on one side, and the SHIW, on the other. These differences are due partly to irreconcilable diversities in classifications and definitions, partly to shortcomings in both micro and macro sources. Divergence in both levels and time patterns is a matter of concern and makes it necessary to interpret the SHIW data with prudence, but it would be wrong to blame them alone for the discrepancies. Being aware of their deficiencies, we believe that a more complete and reliable analysis of the SHIW wealth data 
must explicitly account for underestimation. The discussion of the statistical techniques used to adjust the SHIW data is the object of the next section.

\subsection{Corrections For Nonresponses, Nonreporting And Underreporting}

There is ample evidence that the probabilities of avoiding the interview (nonresponse), of being reticent about assets actually owned (nonreporting) and of undervaluing declared asset holdings (underreporting) are typically not independent of wealth. ${ }^{11}$ This observation brings us to discard a simple proportional adjustment to FANA aggregates by constant factors and to prefer methods that take advantage of all available information. We apply three procedures (see Appendix B for details).

- The first procedure exploits the figures on the number of contacts needed in the 1998 survey to obtain an interview, as suggested by D'Alessio and Faiella (2002). Households requiring at least two visits before accepting the interview are assumed to be representative of nonresponding units. Under this assumption, the estimated probability of not participating in the survey at the first visit, conditional on being interviewed at a later visit, is a proxy for the unconditional probability of not participating at all, and can be used to recalculate weights adjusted for differential response rates across households with different characteristics (among which income and wealth). This correction can only partially remedy the underrepresentation in the sample of very rich households.

- A model proposed by Cannari et al. (1990) and refined by Cannari and D'Alessio (1993) is applied to correct for nonreporting and underreporting of financial assets. The method is based on the outcome of a statistical matching of the SHIW data for 1987 with the micro-data from a survey carried out in the same year by the Banca Nazionale del Lavoro (BNLS) on a sample of its customers. It rests on the assumption that the BNLS information on respondents' financial behavior is more reliable, owing to the trust that customers are likely to place in their own bank.

- The third procedure, borrowed from Cannari and D'Alessio (1990), accounts for the nonreporting of dwellings not occupied by their owners. The procedure is based on the assumptions that (a) the empirical distribution of the number of dwellings not used as principal residence recorded in the SHIW is a discrete Poisson distribution (conditional

\footnotetext{
${ }^{11}$ See Cannari et al. (1990), Cannari and D’Alessio (1990, 1992, 1993) and D’Alessio and Faiella (2002). On other surveys see, among others, Statistics Canada (1979), Oja (1986), Avery, Elliehausen and Kennickell (1988), Hayashi, Ando and Ferris (1988), Curtin, Juster, and Morgan (1989), Juster and Kuester (1991), Antoniewicz (2000), Kennickell (2000), Davies and Shorrocks (2000), Morissette, Zhang, and Drolet (2002).
} 
on certain household characteristics), and (b) the probability of the owners declaring such dwellings is a binomial distribution. Together, these assumptions imply that the probability of owning a dwelling other than one's own residence also follows a Poisson distribution. This distribution can be estimated and used to impute ownership.

These procedures significantly affect the SHIW evidence. With regard to dwellings, we have already noticed how the adjustment for nonresponse brings the number of owneroccupied houses perfectly into line with the Census total, while it improves only marginally the estimate for the other dwellings. The latter discrepancy is adjusted through the third procedure, even if the stochastic nature of the correction leads to an overshooting of the Census figure by around 7 percent (Table 1).

Table 3 shows the cumulative impact of the various corrections. In 2000 the share of households without any financial assets falls from 19 to 16 percent after correcting for nonresponse; it drops to 7 percent after adjusting also for non and underreporting. Owing to these adjustments, the proportions of holders of transaction and saving accounts and of government debt rise on average by 15 and 13 percentage points respectively, while that of holders of private bonds, equities and mutual funds goes up by 5 percentage points. ${ }^{12}$ The share of proprietors of dwellings increases by about 1 percentage point every year with the adjustment for nonresponses, and by a further 2 to 5 points with the adjustment for non- and underreporting. The latter has declined steadily over time, thanks to better controls on the SHIW fieldwork, and a probable reduction in tax evasion, and hence household reticence, brought about by the introduction of the municipality tax on real estate. In general, the imputation affects mainly households in the lower tail of the wealth distribution. The older and the less educated the household's head, the higher is the size of the adjustment. The correction is larger for households headed by a female, or a self-employed or non-employed person.

Taking the average over the six waves from 1989 to 2000, the adjustments increase the mean values of real estate and financial assets by 31 and 148 percent, respectively (Table 3). The value of household debts is only affected by the adjustment for nonresponse and it is raised by 5 percent ( 9 percent in 2000). Overall, household net worth increases by 41 percent. The shortfall with respect to FANA aggregates is reduced from 75 to 39 percent for

\footnotetext{
${ }^{12}$ The fact that the correction for nonreporting is based on data for 1987 may lead to an insufficient adjustment for equities and investment funds to the extent that their possession was less common in 1987 than in more recent years.
} 
total financial assets, from 26 to 8 percent for tangible assets, and from 41 to 17 percent for net worth (Table 2). In a few cases our procedures lead to estimates exceeding the FANA values. The corrections, and therefore the remaining discrepancies vis-à-vis aggregate figures, vary considerably from year to year: the adjusted SHIW data capture between a minimum of 73 percent of the FANA net worth in 1993 and a maximum of 91 percent in 1998.

In general, the adjustments bring the composition of household wealth closer into line with the aggregate evidence. If we compute the differences, in absolute value, between the SHIW and the aggregate shares in net worth, we find that they fall considerably, after the adjustments, in all waves and for every one of the six components reported in Table 2 except debt. By averaging it out across all waves, the sum of the absolute discrepancies diminishes from 38 percent on unadjusted data to 22 percent on adjusted data.

This summary of the more detailed figures reported in the tables shows the substantial impact of the correction procedures on the SHIW evidence. Our adjustments are meant to offer a more realistic description of the distribution of household wealth in Italy. However, our adjusted results might be regarded with some suspicion because of an excess of manipulation. In the light of this consideration, in the following sections we focus on figures adjusted for nonresponse, nonreporting and underreporting, but we report and occasionally discuss also unadjusted figures. 


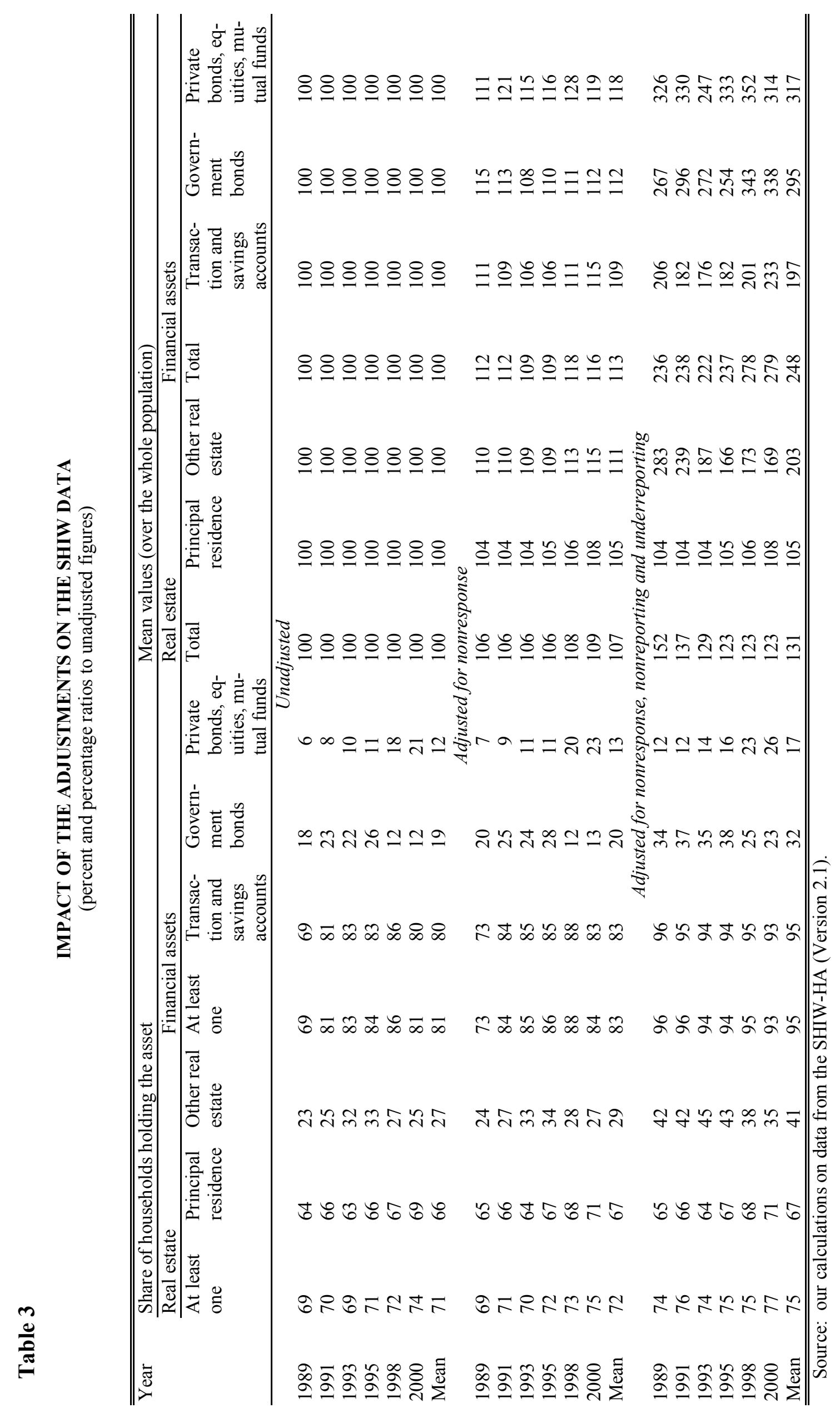




\section{MICROECONOMIC EVIDENCE ON HOUSEHOLD NET WORTH}

At the end of 2000, the adjusted average net worth of Italian households amounted to 270,000 euros, one third more than in 1989 after correcting for changes in the consumer price index (Table 4). ${ }^{13}$ Between 1989 and 2000 mean wealth has been growing in real terms by 2.7 percent per year, while real disposable income has remained virtually unchanged. Apart from capital gains on some asset holdings, this sustained pace of wealth accumulation has been made possible by the high propensity to save of Italian households.

Tangible assets account for the largest, if falling, share of wealth: 73 percent in 2000. The predominance of real assets is largely attributable to homeownership, which in Italy is among the highest in the European Union. ${ }^{14}$ In 2000 the principal residence was worth, across all households, an average of 101,600 euros, or 38 percent of total wealth. Between 1989 and 2000 this value went up by 61 percent in real terms, as a result of an increase in homeownership (from 65 to 71 percent) and residence size (from 111 to 118 square meters), but above all owing to an exceptional rise in housing prices, which exceeded by 40 percent that of consumer prices. The other real estate properties made up 19 percent of net worth in 2000, much less than in 1989. As to the other tangible assets, businesses, consumer durable goods and valuables accounted for 7, 6 and 2 percent of wealth, respectively.

From 1989 to 2000, total financial assets went up from 21 to 29 percent of wealth, growing by 6 percent per year in real terms. This increase was largely driven by investments in risky assets: the mean real value of private bonds, equities and mutual funds rose by 17 percent per year, which caused their share in wealth to expand from 3 to 13 percent. This substantial shift in household portfolios towards risky assets probably reflects both a true reallocation and the rocketing stock market prices of the late 1990s. Although household debt increased much more rapidly than gross wealth, its share of wealth appears to be low in comparison with the FANA statistics.

\footnotetext{
${ }^{13}$ We focus on the comparison between 1989 and 2000 for both statistical and economic reasons. First, the discrepancy between the SHIW estimate for net worth and its aggregate counterpart was relatively low and similar in the two waves. Second, in both years the economic cycle was close to peak.

${ }^{14}$ According to the Eurostat's European Community Household Panel (ECHP), in 1998 the proportion of households owning their house of residence was 71 percent in Italy as compared with 69 in the United Kingdom, 59 in Sweden, 53 in France and 41 in Germany; the proportion was higher only in Greece and Ireland (74 percent) and especially Spain (82 percent). The ECHP fraction of homeowners is somewhat higher than in the SHIW because it includes houses occupied in usufruct.
} 


\section{Table 4}

HOUSEHOLD NET WORTH IN THE SHIW

(euros and percent)

\begin{tabular}{|c|c|c|c|c|c|}
\hline \multirow[t]{2}{*}{ Wealth component } & \multicolumn{2}{|c|}{ Mean values } & \multicolumn{2}{|c|}{ Share in net worth } & \multirow{2}{*}{$\begin{array}{l}\text { Annualized } \\
\text { growth rate } \\
1989-2000\end{array}$} \\
\hline & 1989 & 2000 & 1989 & 2000 & \\
\hline & \multicolumn{5}{|c|}{ Unadjusted } \\
\hline Total tangible assets & 115,300 & 164,200 & 87.7 & 87.1 & 3.3 \\
\hline Consumer durable goods & 16,800 & 16,300 & 12.8 & 8.6 & -0.3 \\
\hline Jewelry and other valuables & 3,500 & 3,900 & 2.7 & 2.1 & 1.0 \\
\hline Principal residence & 60,600 & 94,500 & 46.1 & 50.1 & 4.1 \\
\hline Other real estate & 22,400 & 30,900 & 17.0 & 16.4 & 3.0 \\
\hline Businesses & 12,100 & 18,500 & 9.2 & 9.8 & 3.9 \\
\hline Total financial assets & 17,800 & 27,900 & 13.5 & 14.8 & 4.2 \\
\hline Transaction and savings accounts & 10,800 & 13,100 & 8.2 & 6.9 & 1.8 \\
\hline Government bonds & 5,200 & 4,000 & 4.0 & 2.1 & -2.4 \\
\hline Private bonds, equities, mutual funds & 1,800 & 10,700 & 1.4 & 5.7 & 17.6 \\
\hline Gross wealth & 133,100 & 192,000 & 101.2 & 101.8 & 3.4 \\
\hline Debt & 1,600 & 3,400 & 1.2 & 1.8 & 7.1 \\
\hline Net worth & 131,500 & 188,600 & 100.0 & 100.0 & 3.3 \\
\hline \multirow[t]{2}{*}{ Disposable income (1) } & 26,000 & 26,400 & - & - & 0.1 \\
\hline & \multicolumn{5}{|c|}{ Adjusted } \\
\hline Total tangible assets & 160,500 & 195,500 & 80.0 & 72.5 & 1.8 \\
\hline Consumer durable goods & 17,700 & 17,300 & 8.8 & 6.4 & -0.2 \\
\hline Jewelry and other valuables & 3,600 & 4,300 & 1.8 & 1.6 & 1.6 \\
\hline Principal residence & 63,000 & 101,600 & 31.4 & 37.7 & 4.4 \\
\hline Other real estate & 63,300 & 52,400 & 31.5 & 19.4 & -1.7 \\
\hline Businesses & 12,800 & 19,900 & 6.4 & 7.4 & 4.1 \\
\hline Total financial assets & 41,900 & 77,900 & 20.9 & 28.9 & 5.8 \\
\hline Transaction and savings accounts & 22,300 & 30,600 & 11.1 & 11.4 & 2.9 \\
\hline Government bonds & 13,800 & 13,500 & 6.9 & 5.0 & -0.2 \\
\hline Private bonds, equities, mutual funds & 5,800 & 33,700 & 2.9 & 12.5 & 17.3 \\
\hline Gross wealth & 202,400 & 273,400 & 100.8 & 101.4 & 2.8 \\
\hline Debt & 1,600 & 3,700 & 0.8 & 1.4 & 7.9 \\
\hline Net worth & 200,700 & 269,600 & 100.0 & 100.0 & 2.7 \\
\hline Disposable income (1) & 29,700 & 29,800 & - & - & 0.0 \\
\hline
\end{tabular}

Source: our calculations on data from the SHIW-HA (Version 2.1). Figures may not add up to totals because of rounding. Mean values are expressed at 2000 prices by using the consumer price index and are rounded to hundreds of euros. (1) Total household income net of taxes and social security contributions. 


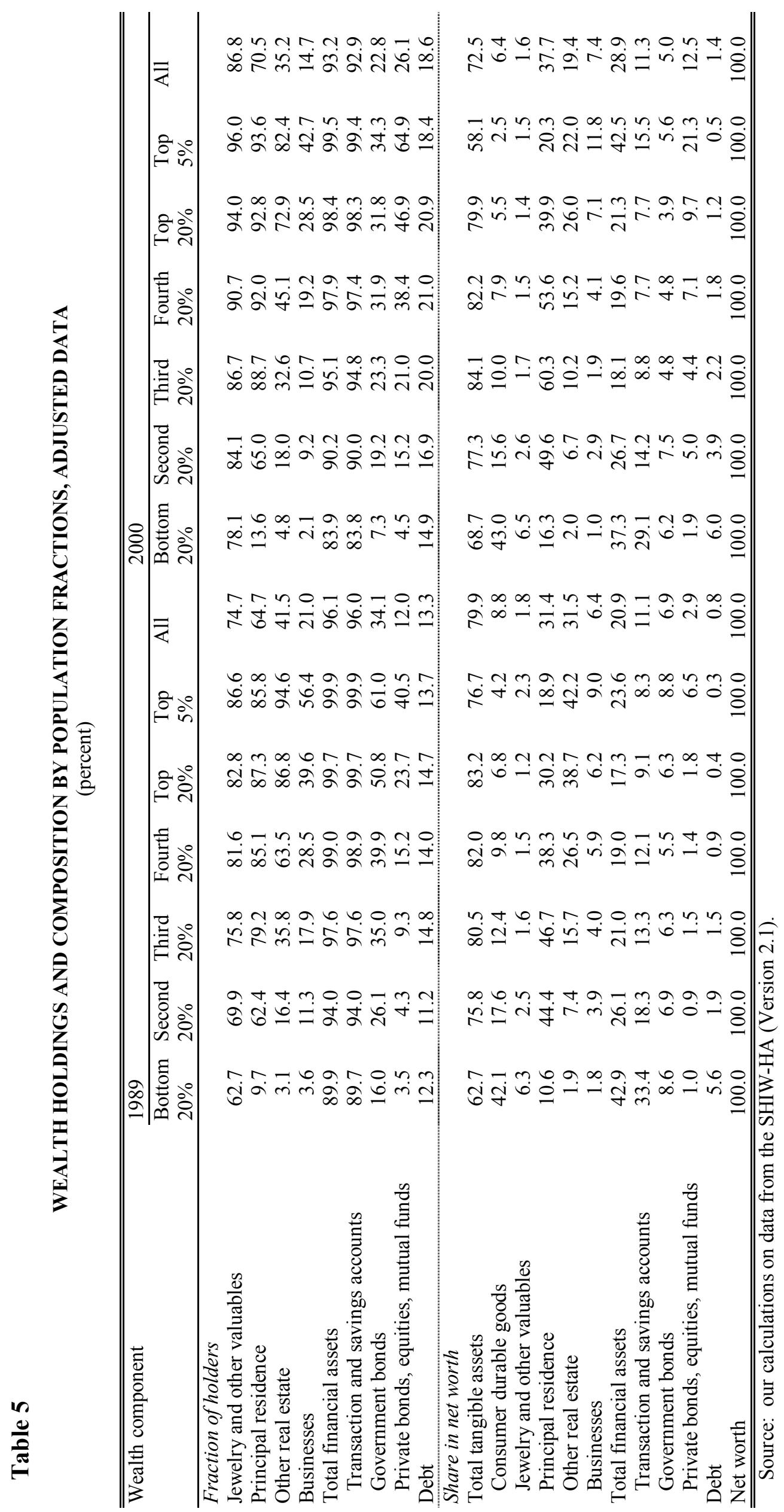


All in all, the unadjusted figures do not contradict this basic picture. However, the share of tangible assets is constantly higher than in the adjusted data and, over the period, the shift towards financial assets looks substantially less pronounced; also changes in the value of other real estate are rather different. On the other hand, the mean values of principal residence, businesses, and private bonds, equities and mutual funds rise at very similar annual growth rate.

Asset holdings and wealth composition vary considerably across classes of the population ranked by wealth (Table 5). In the bottom fifth of the population, consumer durables account for the largest fraction of net worth, followed by transaction and savings accounts (43 and 29 percent, respectively, in 2000). As much as 16 percent of the poorest had no bank or postal account in 2000. In middle classes an overwhelming proportion of wealth is held in the form of real estate, among which the principal residence represents the largest share. Businesses and risky financial assets are most frequent among the richest households. In 2000, 43 percent of the most affluent twentieth of the population had businesses and 65 percent possessed private bonds, equities or mutual funds. While the ownership of equities and mutual funds spread across all classes during the 1990s, their amount has come to account for a large proportion of portfolios only among the very rich. In 2000 , the top 5 percent held over 20 percent of net worth in these assets compared with 4 to 7 percent in the middle classes and 2 percent in the poorest fifth.

The cross-section age profile of wealth holdings exhibits the usual hump-shaped pattern. (Of course, as underlined by Shorrocks, 1975, this pattern has no implications for the shape of the lifetime profile of wealth ownership. On the age-wealth pattern in the SHIW data see also Jappelli and Pistaferri, 2000.) We can make two observations, which parallel analogous comments for household incomes (Brandolini and D'Alessio, 2003). First, some inter-generational redistribution substantially changed the relationship between 1989 and 2000: the net worth of households whose head is older than 65 increased from 81 to 114 percent of the average, while that of those with younger heads fell from 90 to 67 percent (Figure 3, left-hand panel). This shift could be due to the ageing of cohorts whose wealth accumulation benefited from the high growth of the Italian economy in the 1950s and 1960s and the gradual advent of a relatively generous pension system. It also shows up in the improved condition of retired heads relative to salaried and self-employed heads (Figure 4, left-hand panel). The second observation is that the curvature of the age profile in Italy is much less pronounced than in Canada and the United States (Figure 3, right-hand panel). The smaller differences in wealth holdings across generations in Italy may follow from a 
generally lower degree of wealth concentration, or a more composite household structure, whereby the coexistence of several generations within the household makes the classification based on the head's age less significant than in the two north American countries.

\section{Figure 3}

\section{AGE PROFILE OF NET WORTH}

(percentage ratio to total mean)
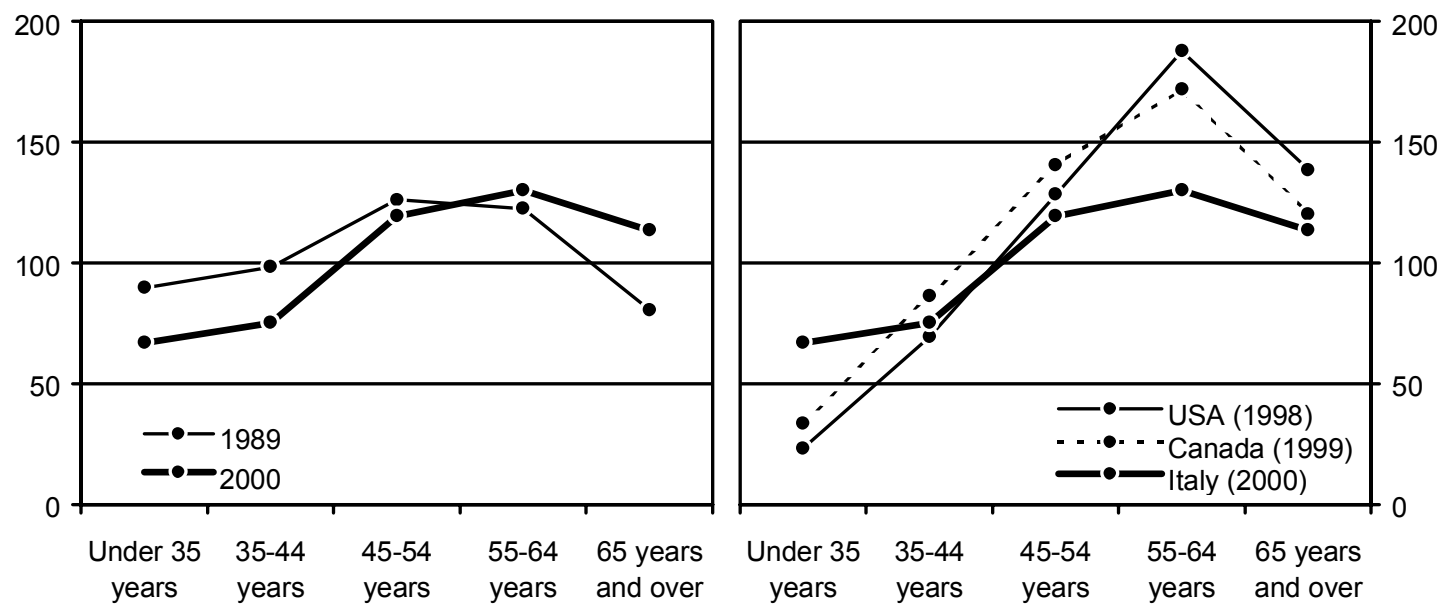

Source: our calculations on data from the SHIW-HA (Version 2.1) for Italy; Kennickell, Starr-McCluer, and Surette (2000), Tables 1 and 3, pp. 5 and 7, for the United States; Morissette, Zhang, and Drolet (2002), Table 8, p. 29, for Canada.

With regard to regional differences, the average household wealth is higher in the North and the Centre than in the South and Islands, as a reflection of the different levels of economic development (Figure 4, right-hand panel; see also Magnani, 1997, Cannari, D'Alessio, and Venturini, 2003, and Cannari and D'Alessio, 2002, for further evidence on household wealth across Italian regions). This gap is also likely to be influenced by the greater number of children in southern families. For instance, in 1989 household heads aged between 31 and 40 had on average 2 living sisters or brothers in the Centre-North compared with 2.8 in the South. The impact of the larger household size is twofold: it reduces resources available for the accumulation of wealth during life; it brings about a higher fragmentation of inheritance at the death of wealth-holders. A significant change in the geographical distribution of net worth took place during the 1990s, as the North-South ratio widened from 1.4 in 1989 to 2.1 in 2000. 


\section{Figure 4}

NET WORTH BY WORK STATUS AND GEOGRAPHICAL AREA

(percentage ratio to total mean)
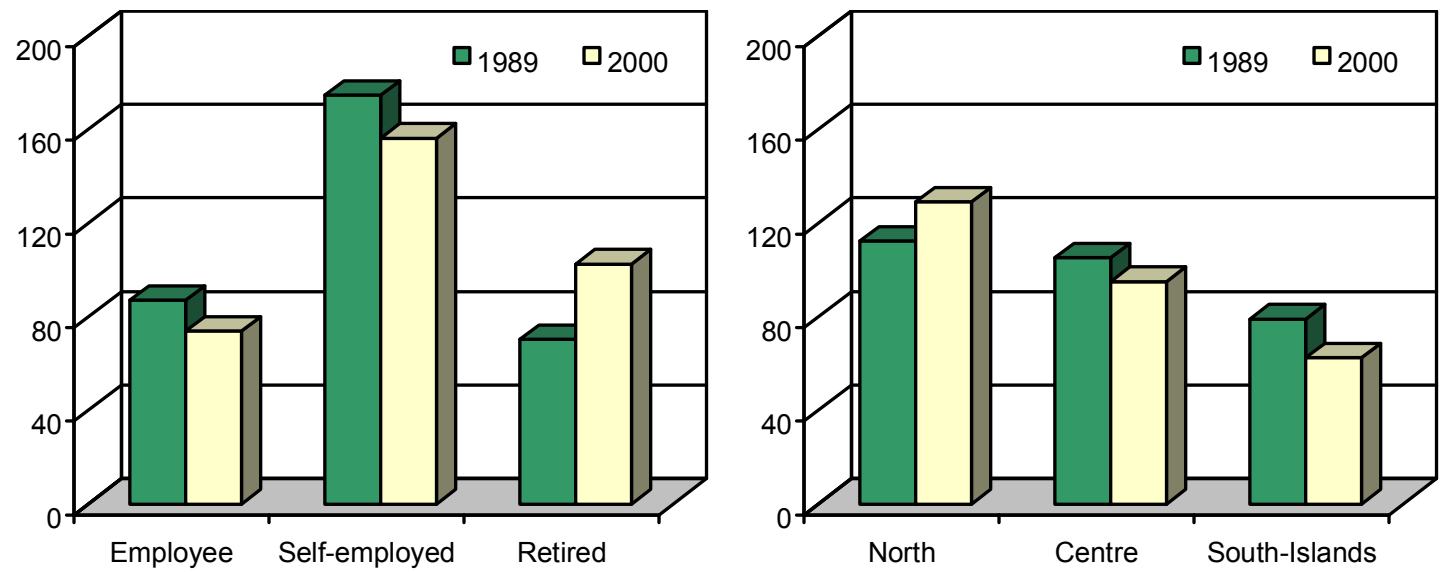

Source: our calculations on data from the SHIW-HA (Version 2.1).

\section{WEALTH INEQUALITY}

The distribution of household wealth in Italy exhibits the highly asymmetric profile found in most countries (Figure 5). In 2000 median wealth was 143,000 euros, or 53.1 percent of the mean (Table 6). The 95th percentile of the wealth distribution was 5.8 times the median, while the 95th percentile of the income distribution was 2.8 times. The share in total wealth of the bottom 40 percent of Italian households, ranked in ascending order by net worth, was only 7 percent, and that of the next 40 percent was 29 percent; the remaining 64 percent was held by the most affluent fifth of the population. The richest 1 percent of households possessed 17 percent of total wealth. ${ }^{15}$ The Gini index of concentration was 0.61 , a much

\footnotetext{
${ }^{15}$ Despite our adjustments, the share of the richest households is underestimated owing to their underrepresentation. To obtain some understanding, however imprecise, of the size of the wealth controlled by the wealthiest, we checked the world ranking published by Forbes Magazine of (known) billionaires in U.S. dollars. In 2002, 13 Italian families appeared in Forbes Magazine (2002) for a total wealth estimated at 35 billion dollars, or 0.6 percent of aggregate household net worth. This proportion compares to the 1.5 percent owned by the 61 richest families in the United States and 2.6 percent owned by the 7 richest families in Canada.
} 
higher value than the 0.37 found for disposable income. The values of the Gini index are higher for unadjusted data in 1989-1995; they are lower in 1998-2000. ${ }^{16}$

\section{Figure 5}

\section{KERNEL DENSITY ESTIMATION OF THE DISTRIBUTIONS OF HOUSEHOLD NET WORTH AND DISPOSABLE INCOME}



Source: our calculations on data from the SHIW-HA (Version 2.1). Non-parametric estimation techniques implemented using STATA 7.0. Values bottom-coded at the 1st percentile and top-coded at the 99th percentile. Epanechnicov function is used as kernel and bandwith is selected following a criterion that approximately minimizes the asymptotic mean integrated square error (AMISE). See Pagan and Ullah (1999), pp. 49-54.

Inequality slightly fell from 1989 to 1991 and then trended sharply upwards in the rest of the decade (Figure 6). The Gini index diminished from 0.55 in 1989 to 0.54 in 1991, jumped to 0.58 in 1993 and rose further to 0.61 in 1998. Unadjusted data convey the impression of a more stable distribution. However, regardless of whether data are adjusted or not, the Gini index in 1989 is much lower than in 2000, and the difference is significant at the 1 percent level. ${ }^{17}$ This conclusion carries over to all Lorenz-consistent inequality measures, since the Lorenz curve for 1989 lies above that for 2000 at all vingtile points.

\footnotetext{
${ }^{16}$ The correction for nonresponse tends to increase concentration. On the contrary, correcting for non and underreporting has a mixed impact but predominantly in the direction of reducing dispersion. This pattern is the net outcome of two different effects (Cannari and D'Alessio, 1993): (a) the adjustment for non-reporting tends to reduce inequality, because all wealthy households declare they hold bank deposits and, most of them, government bonds; (b) the correction for underreporting leads to an increase in inequality, as the phenomenon matters more for those financial assets, such as private securities, investment fund shares and corporate equities, held to a much greater extent by the wealthy.

${ }^{17}$ The null hypothesis of equality of the two indices is tested by the asymptotically standard normal statistic $T_{i j}=\left(G_{i}-G_{j}\right) /\left(s e_{i}^{2}+s e_{j}^{2}\right)^{0.5}$, where $G_{i}$ and $s e_{i}$ are the values of the Gini ratio and of its standard error in year $i$, respectively. Since this test applies only to independent samples, it is not appropriate for pair comparisons
} 
Table 6

STATISTICS OF THE DISTRIBUTION OF HOUSEHOLD NET WORTH

\begin{tabular}{|c|c|c|c|c|c|c|}
\hline Statistic & 1989 & 1991 & 1993 & 1995 & 1998 & 2000 \\
\hline & \multicolumn{6}{|c|}{ Unadjusted } \\
\hline \multicolumn{7}{|l|}{ Population share (1) } \\
\hline Bottom 40 percent & 7.8 & 7.1 & 5.4 & 6.1 & 5.8 & 6.4 \\
\hline Next 40 percent & 34.6 & 35.5 & 33.2 & 33.8 & 32.0 & 31.4 \\
\hline Top 20 percent & 57.6 & 57.5 & 61.4 & 60.1 & 62.3 & 62.1 \\
\hline Top 10 percent & 40.0 & 39.2 & 43.4 & 42.3 & 45.6 & 45.7 \\
\hline Top 5 percent & 27.1 & 26.0 & 29.7 & 28.9 & 32.5 & 32.9 \\
\hline Top 1 percent & 10.2 & 9.0 & 11.7 & 10.6 & 13.8 & 14.0 \\
\hline Half squared coefficient of variation & 1.007 & 0.857 & 1.378 & 1.143 & 1.974 & 1.651 \\
\hline Gini index & 0.555 & 0.558 & 0.601 & 0.586 & 0.607 & 0.601 \\
\hline s.e. (2) & 0.010 & 0.010 & 0.010 & 0.009 & 0.012 & 0.011 \\
\hline Mean (3) & 131,500 & 148,800 & 169,300 & 168,400 & 179,800 & 188,600 \\
\hline \multirow[t]{2}{*}{ Median (3) } & 84,000 & 94,700 & 98,800 & 102,100 & 105,500 & 108,500 \\
\hline & \multicolumn{6}{|c|}{ Adjusted } \\
\hline \multicolumn{7}{|l|}{ Population share (1) } \\
\hline Bottom 40 percent & 8.3 & 8.2 & 6.9 & 7.2 & 6.6 & 7.0 \\
\hline Next 40 percent & 33.8 & 35.2 & 33.2 & 33.2 & 29.9 & 29.2 \\
\hline Top 20 percent & 57.9 & 56.6 & 60.0 & 59.5 & 63.5 & 63.8 \\
\hline Top 10 percent & 40.2 & 38.7 & 42.0 & 42.1 & 47.5 & 48.5 \\
\hline Top 5 percent & 27.3 & 25.6 & 28.3 & 29.0 & 34.8 & 36.4 \\
\hline Top 1 percent & 10.6 & 9.3 & 11.2 & 10.7 & 15.5 & 17.2 \\
\hline Half squared coefficient of variation & 1.063 & 0.860 & 1.215 & 1.106 & 2.044 & 2.345 \\
\hline Gini index & 0.553 & 0.543 & 0.579 & 0.573 & 0.611 & 0.613 \\
\hline s.e. (2) & 0.010 & 0.011 & 0.010 & 0.009 & 0.015 & 0.016 \\
\hline Mean (3) & 200,700 & 210,500 & 228,800 & 223,300 & 256,300 & 269,600 \\
\hline Median (3) & 121,900 & 132,300 & 135,400 & 133,900 & 138,700 & 143,100 \\
\hline
\end{tabular}

Source: our calculations on data from the SHIW-HA (Version 2.1). (1) Percentage values. Figures may not add up to 100 because of rounding. (2) Asymptotic standard errors of the Gini index calculated according to the formula derived by Cowell (1989), assuming known mean of sample weights. (3) Euros at 2000 prices, rounded to hundreds.

The comparison of the shares in Table 6 shows that the worsening of wealth inequality from 1989 to 2000 was caused by large gains concentrated at the very top of the distribution: the richest 5 percent increased their share by 9.1 percentage points at the expense of the remaining 95 percent of the population. This movement is evident in Figure 6 in the stretching to the right of the frequency distribution.

among figures referring to surveys that include a panel section like the SHIW. To the extent that the panel section leads to a positive correlation between estimates in subsequent years, the use of the statistic $T_{i j}$ should make rejection of the null hypothesis less likely. 
Figure 6

GINI INDEX FOR HOUSEHOLD NET WORTH
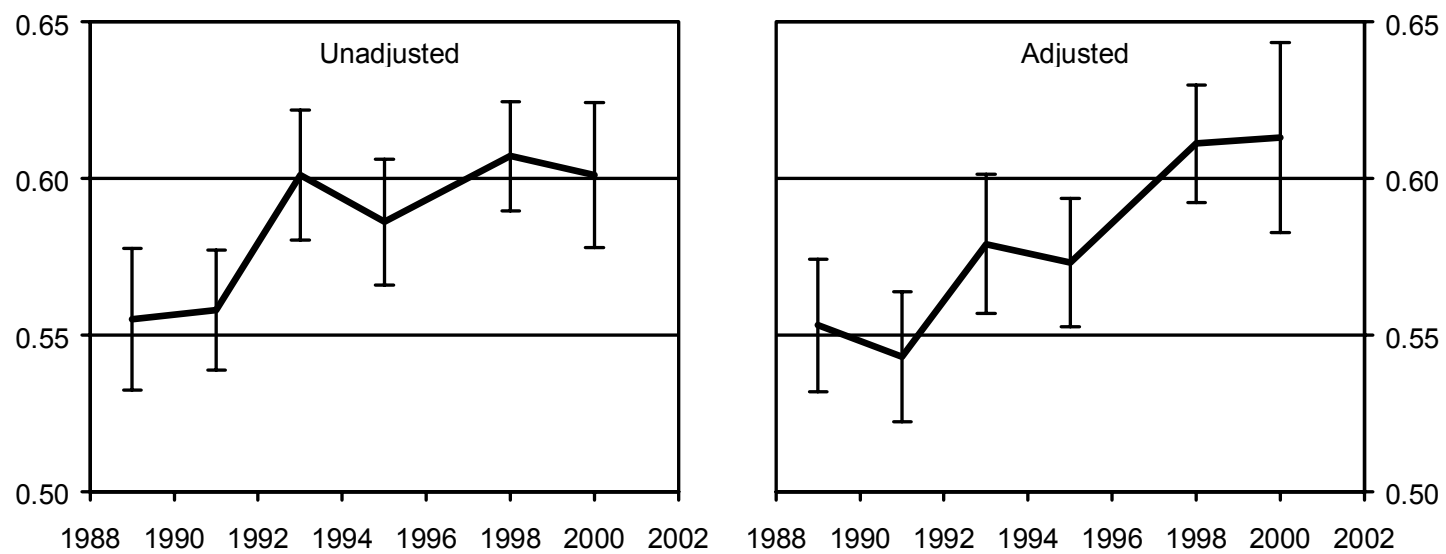

Source: our calculations on data from the SHIW-HA (Version 2.1). On both sides, bars equal twice the standard error. Asymptotic standard errors are calculated according to the formula derived by Cowell (1989), assuming known mean of sample weights.

The distribution of financial wealth widened during the 1990s at a much faster pace than the distribution of net worth. The concentration of the ownership of financial assets rose dramatically: the Gini index went up from 0.66 in 1991 to 0.81 in 2000 (Figure 7). The distribution of tangible assets became only slightly more unequal, after some narrowing between 1989 and 1991. Liabilities, in turn, remained very concentrated. The picture based on unadjusted data is less neat, but it does not contrast with that just described.

In the next two sections, we decompose the inequality indices to investigate how the observed shift in household portfolios towards risky assets and the different degree of concentration of single wealth components impinge on the changes in overall inequality.

\section{Figure 7}

GINI INDEX FOR HOUSEHOLD WEALTH COMPONENTS

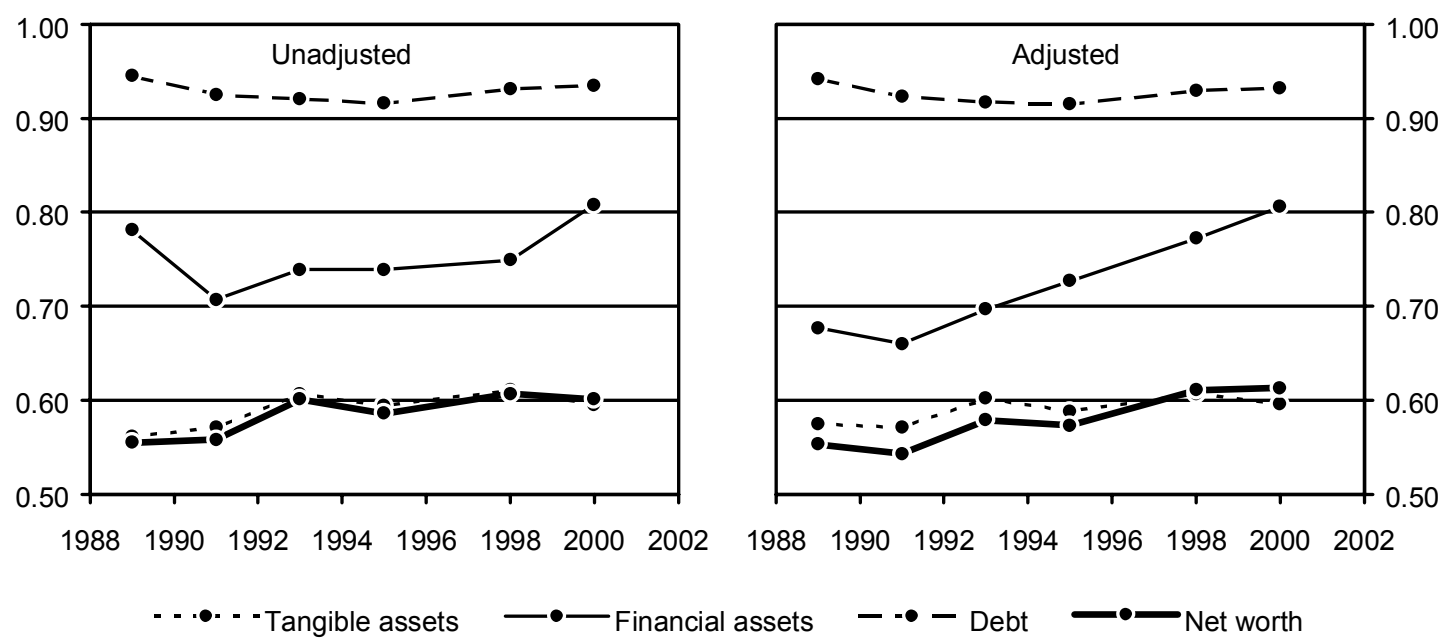

Source: our calculations on data from the SHIW-HA (Version 2.1). 


\subsection{Decomposition Of Inequality By Wealth Components}

To understand how the distributions of tangible assets, financial assets and debt combine to produce the overall degree of inequality, we resort to the decomposition of the Gini index proposed by Pyatt, Chen, and Fei (1980). The Gini coefficient $G$ of net worth $w$ can be factorized as:

$$
G=\sum_{k=1}^{3}\left(\frac{\mu_{k}}{\mu}\right) G_{k} R
$$

where $\mu$ is the mean wealth, $\mu_{k}$ is the mean of wealth component $k$, with $\mu=\Sigma_{k} \mu_{k}, G_{k}$ is the Gini index of wealth component $k$, and $R=\operatorname{cov}\left[w_{k}, r(w)\right] / \operatorname{cov}\left[w_{k}, r\left(w_{k}\right)\right]$ is the "rank correlation ratio," with $r(x)$ being the ranking of households according to variable $x$. The rank correlation ratio is equal to unity only if $r(w)=r\left(w_{k}\right)$, i.e. if households have the same ranking with respect to $w$ and $w_{k}$. The results of the Gini decomposition are reported in the first five columns of Table 7. 
Table 7

DECOMPOSITION OF THE GINI INDEX AND THE VARIANCE BY WEALTH COMPONENTS

\begin{tabular}{|c|c|c|c|c|c|c|c|}
\hline \multirow[t]{2}{*}{ Wealth component } & \multicolumn{5}{|c|}{ Decomposition of the Gini index } & \multicolumn{2}{|c|}{ Variance decomposition } \\
\hline & $\begin{array}{l}\text { Percentage } \\
\text { share in net } \\
\text { worth }\end{array}$ & Gini index & $\begin{array}{l}\text { Rank } \\
\text { correlation } \\
\text { ratio } \\
\end{array}$ & $\begin{array}{l}\text { Absolute } \\
\text { contribu- } \\
\text { tion } \\
\end{array}$ & $\begin{array}{l}\text { Percentage } \\
\text { contribu- } \\
\text { tion }\end{array}$ & $\begin{array}{l}\text { Absolute } \\
\text { contribu- } \\
\text { tion (1) }\end{array}$ & $\begin{array}{l}\text { Percentage } \\
\text { contribu- } \\
\text { tion }\end{array}$ \\
\hline \multicolumn{8}{|l|}{1989} \\
\hline Tangible assets & 80.0 & 0.575 & 0.971 & 0.447 & 80.8 & 24,426 & 67.5 \\
\hline Financial assets & 20.9 & 0.677 & 0.759 & 0.107 & 19.4 & 11,806 & 32.6 \\
\hline Debt & -0.8 & 0.942 & 0.154 & -0.001 & -0.2 & -42 & -0.1 \\
\hline Net worth & 100.0 & 0.553 & 1.000 & 0.553 & 100.0 & 36,190 & 100.0 \\
\hline \multicolumn{8}{|l|}{1991} \\
\hline Tangible assets & 83.1 & 0.571 & 0.973 & 0.462 & 85.0 & 34,230 & 83.0 \\
\hline Financial assets & 18.2 & 0.660 & 0.699 & 0.084 & 15.5 & 7,123 & 17.3 \\
\hline Debt & -1.3 & 0.923 & 0.216 & -0.003 & -0.5 & -116 & -0.3 \\
\hline Net worth & 100.0 & 0.543 & 1.000 & 0.543 & 100.0 & 41,237 & 100.0 \\
\hline \multicolumn{8}{|l|}{1993} \\
\hline Tangible assets & 82.8 & 0.602 & 0.976 & 0.487 & 84.1 & 68,184 & 81.8 \\
\hline Financial assets & 18.7 & 0.697 & 0.733 & 0.095 & 16.5 & 15,331 & 18.4 \\
\hline Debt & -1.5 & 0.917 & 0.236 & -0.003 & -0.6 & -135 & -0.2 \\
\hline Net worth & 100.0 & 0.579 & 1.000 & 0.579 & 100.0 & 83,380 & 100.0 \\
\hline \multicolumn{8}{|l|}{1995} \\
\hline Tangible assets & 81.2 & 0.588 & 0.971 & 0.464 & 80.9 & 66,153 & 76.3 \\
\hline Financial assets & 20.4 & 0.727 & 0.772 & 0.114 & 19.9 & 20,890 & 24.1 \\
\hline Debt & -1.5 & 0.915 & 0.330 & -0.005 & -0.8 & -300 & -0.3 \\
\hline Net worth & 100.0 & 0.573 & 1.000 & 0.573 & 100.0 & 86,743 & 100.0 \\
\hline \multicolumn{8}{|l|}{1998} \\
\hline Tangible assets & 73.9 & 0.607 & 0.965 & 0.433 & 70.8 & 156,465 & 63.3 \\
\hline Financial assets & 27.3 & 0.772 & 0.859 & 0.181 & 29.7 & 91,310 & 36.9 \\
\hline Debt & -1.2 & 0.929 & 0.278 & -0.003 & -0.5 & -571 & -0.2 \\
\hline Net worth & 100.0 & 0.611 & 1.000 & 0.611 & 100.0 & 247,204 & 100.0 \\
\hline \multicolumn{8}{|l|}{2000} \\
\hline Tangible assets & 72.5 & 0.596 & 0.960 & 0.415 & 67.7 & 155,614 & 45.6 \\
\hline Financial assets & 28.9 & 0.806 & 0.871 & 0.203 & 33.0 & 185,948 & 54.5 \\
\hline Debt & -1.4 & 0.932 & 0.326 & -0.004 & -0.7 & -609 & -0.2 \\
\hline Net worth & 100.0 & 0.613 & 1.000 & 0.613 & 100.0 & 340,953 & 100.0 \\
\hline
\end{tabular}

Source: our calculations on data from the SHIW-HA (Version 2.1). Figures may not add up to totals because of rounding. (1) Divided by $10^{6}$.

In all years the rank correlation ratio for tangible assets is very close to one, suggesting that the ranking of households in terms of tangible wealth is very similar to that in terms of net worth. The proportion of total inequality accounted for by tangible assets fell from 81 percent in 1989 to 68 percent in 2000. Conversely, the contribution of financial assets grew from 19 to 33 percent, as a result of its increased weight in net worth and its much higher concentration. Ceteris paribus, if the value of the Gini index of financial assets had been the same in 2000 as in 1989 (i.e. 0.677 instead 0.806), the decomposition in Table 7 suggests that the Gini index of net worth would have been around 0.58 , or 3 percentage points below its actual value. Alternatively, had the Gini index of tangible assets remained unchanged at 0.575 rather than increasing to 0.596 , net worth would have shown a Gini index 1.5 points 
below its historical value. Lastly, keeping the wealth composition unchanged, the Gini index would fall by 1.2 points. This simple decomposition exercise confirms that it was chiefly the considerable increase in the concentration of financial wealth that imparted the inegalitarian twist to the overall distribution observed in the 1990s.

Shorrocks (1983) criticized this decomposition of the Gini index on the grounds that it is one of an infinite variety of potential rules and that it is then arbitrary to choose it over any other. To counter this objection we have also reported in the last two columns of Table 7 the results from applying the unique decomposition rule proposed by Shorrocks, whereby the contribution of wealth component $k$ to total inequality is equal to $\operatorname{cov}\left(w, w_{k}\right) / \operatorname{var}(w)$. The proportion of inequality attributed to financial assets is constantly higher with Shorrocks' rule than with the previous rule; the difference is especially marked in 1989 and 2000. However, the two inequality decompositions provide a consistent picture of the time pattern: they both point to a remarkable increase in the role of financial assets in explaining total wealth inequality - an increase which is even greater with the variance decomposition than the Gini decomposition.

\subsection{Decomposition Of Inequality By Population Subgroups}

A second way to identify the factors behind changes in the size distribution of wealth is through the decomposition of inequality indices by homogeneous subgroups of the population. The aim of the decomposition is to distinguish the inequality within the groups from the inequality among the groups. In examining variations over time, we also have to consider the effect of changes in the relative size of the groups. Since the Gini index is not exactly decomposable by population subgroups, we turn to an index of the class of entropy measures characterized by Cowell (1980) and Shorrocks (1980), the half squared coefficient of variation:

$$
E=\frac{1}{2}\left[\frac{1}{n} \sum_{i=1}^{n}\left(\frac{w_{i}}{\mu}\right)^{2}-1\right]
$$

where $w_{i}$ is the wealth of household $i$ and $n$ is the number of households. If households are partitioned into $K$ groups according to some characteristic, the overall inequality index $E$ can be exactly decomposed into within-groups, $E^{W}$, and between-groups, $E^{B}$, as follows:

$$
E=E^{W}+E^{B}=\sum_{k=1}^{K} p_{k}\left(\frac{\mu_{k}}{\mu}\right)^{2} E_{k}+\frac{1}{2}\left[\sum_{k=1}^{K} p_{k}\left(\frac{\mu_{k}}{\mu}\right)^{2}-1\right],
$$


where subscript $k$ now denotes a population subgroup and $p_{k}, \mu_{k}$ and $E_{k}$ are the respective population share, average wealth, and half squared coefficient of variation. To isolate the impact of changes in population share, we rewrite (3) as

$$
E=E^{\bar{W}}+E^{\bar{B}}+E^{P}=\sum_{k=1}^{K} \bar{p}_{k}\left(\frac{\mu_{k}}{\bar{\mu}}\right)^{2} E_{k}+\frac{1}{2}\left[\sum_{k=1}^{K} \bar{p}_{k}\left(\frac{\mu_{k}}{\bar{\mu}}\right)^{2}-1\right]+E^{P},
$$

where we fix the population weights at their values $\bar{p}_{k}$ in a base year and we recalculate the total mean at fixed weights as $\bar{\mu}=\Sigma_{k} \bar{p}_{k} \mu_{k}$. The within- and between-groups addenda in (4) are now net of variations in the relative group sizes, and the effect of a changing population structure is taken up in the residual term $E^{P}$. By construction, $E^{P}=0$ in the base year.

Table 8 contains the results of decomposition (4). In the top panels we check the effect of sorting households by five demographic characteristics: household size, area of residence, sex, age, and education of the household head. For all five characteristics, the overall inequality of net worth is almost entirely attributable to inequality within each group. As seen above, disparities in mean wealth among households residing in different parts of Italy are significant. Decomposition (4) shows, however, that these disparities explain little of the degree of wealth concentration in the country as a whole. What matters is the inequality inside each region. A similar conclusion is reached for the other groupings. For instance, in 2000 the mean wealth of households where the head had a university degree was 2.7 times the mean for households where the head had only completed elementary school. Yet, differences across groups classified by the head's education only account for 5 percent of total inequality. On these bases, it is no surprise that the time pattern of total inequality largely tallies with that of the within-group components.

The same decomposition method can be used to shed some light on the way homeownership and investment in risky assets determine total inequality (bottom two panels of Table 8). Even if the average net worth of homeowners was, in 2000, almost 4 times the average for nonhomeowners, this difference contributed only 4 percent of total inequality. This contribution was somewhat higher in previous years, but not enough to affect the temporal trend of the overall index. The spreading of homeownership, from 65 to 71 percent between 1989 and 2000, slightly reinforced the tendency of inequality to rise, as shown by the constantly negative sign of the relative size effect. This inegalitarian impact is very strong when households are grouped according to whether or not they possessed private bonds, equities or mutual funds. Ceteris paribus, the increase in inequality between 1989 and 2000 would have been about a third less than it actually was had the share of households 
holding the risky assets in 1989 been equal to that in $2000 .{ }^{18}$ This classification also exhibits a greater inter-group inequality than any other of the groupings under consideration, but even in this case removing the full difference between group means would not alter the temporal pattern.

To sum up, the widening of the size distribution of net worth during the last decade was spread across all population groups and can be attributed only marginally to the demographic characteristic examined here. The same consideration carries over to the grouping of households by homeownership. The increase in the proportion of holders of risky assets, on the other hand, appears to have amplified, ceteris paribus, the tendency of inequality to grow.

\footnotetext{
${ }^{18}$ The counter-factual value of the index in 1989 is 1.523 , i.e. the actual value less the relative size effect. The actual change of the index (1.282) therefore compares with a smaller counterfactual change (0.822).
} 
Table 8

DECOMPOSITION OF HALF SQUARED COEFFICIENT OF VARIATION BY POPULATION SUBGROUPS

\begin{tabular}{|c|c|c|c|c|c|c|c|}
\hline \multirow[t]{2}{*}{ Year } & \multicolumn{2}{|c|}{$\begin{array}{l}\text { Within groups } \\
\text { at fixed weights }\end{array}$} & \multicolumn{2}{|c|}{$\begin{array}{l}\text { Between groups } \\
\text { at fixed weights }\end{array}$} & \multicolumn{2}{|c|}{$\begin{array}{l}\text { Group relative } \\
\text { size effect }\end{array}$} & \multirow[t]{2}{*}{ Total } \\
\hline & Value & Share & Value & Share & Value & Share & \\
\hline & \multicolumn{7}{|c|}{ Household size } \\
\hline 1989 & 1.091 & 102.7 & 0.017 & 1.6 & -0.045 & -4.2 & 1.063 \\
\hline 1991 & 0.866 & 100.7 & 0.011 & 1.2 & -0.017 & -1.9 & 0.860 \\
\hline 1993 & 1.114 & 91.7 & 0.029 & 2.4 & 0.071 & 5.9 & 1.215 \\
\hline 1995 & 1.045 & 94.5 & 0.030 & 2.8 & 0.030 & 2.8 & 1.106 \\
\hline 1998 & 2.019 & 98.8 & 0.014 & 0.7 & 0.011 & 0.5 & 2.044 \\
\hline \multirow[t]{2}{*}{2000} & 2.335 & 99.6 & 0.010 & 0.4 & - & - & 2.345 \\
\hline & \multicolumn{7}{|c|}{ Area of residence (1) } \\
\hline 1989 & 1.041 & 97.9 & 0.012 & 1.2 & 0.010 & 0.9 & 1.063 \\
\hline 1991 & 0.837 & 97.3 & 0.014 & 1.7 & 0.009 & 1.0 & 0.860 \\
\hline 1993 & 1.174 & 96.7 & 0.031 & 2.5 & 0.010 & 0.8 & 1.215 \\
\hline 1995 & 1.064 & 96.2 & 0.033 & 3.0 & 0.010 & 0.9 & 1.106 \\
\hline 1998 & 1.998 & 97.8 & 0.037 & 1.8 & 0.009 & 0.4 & 2.044 \\
\hline \multirow[t]{2}{*}{2000} & 2.297 & 98.0 & 0.048 & 2.0 & - & - & 2.345 \\
\hline & \multicolumn{7}{|c|}{ Sex of household head } \\
\hline 1989 & 1.048 & 98.6 & 0.006 & 0.6 & 0.009 & 0.8 & 1.063 \\
\hline 1991 & 0.853 & 99.1 & 0.006 & 0.7 & 0.002 & 0.2 & 0.860 \\
\hline 1993 & 1.197 & 98.5 & 0.017 & 1.4 & 0.001 & 0.1 & 1.215 \\
\hline 1995 & 1.107 & 100.1 & 0.010 & 0.9 & -0.011 & -1.0 & 1.106 \\
\hline 1998 & 2.067 & 101.1 & 0.014 & 0.7 & -0.037 & -1.8 & 2.044 \\
\hline \multirow[t]{2}{*}{2000} & 2.335 & 99.6 & 0.010 & 0.4 & - & - & 2.345 \\
\hline & \multicolumn{7}{|c|}{ Age of household head (2) } \\
\hline 1989 & 1.007 & 94.7 & 0.032 & 3.0 & 0.024 & 2.3 & 1.063 \\
\hline 1991 & 0.816 & 94.9 & 0.021 & 2.4 & 0.023 & 2.7 & 0.860 \\
\hline 1993 & 1.161 & 95.6 & 0.032 & 2.6 & 0.021 & 1.8 & 1.215 \\
\hline 1995 & 1.048 & 94.7 & 0.026 & 2.4 & 0.032 & 2.9 & 1.106 \\
\hline 1998 & 1.973 & 96.5 & 0.012 & 0.6 & 0.058 & 2.9 & 2.044 \\
\hline \multirow[t]{2}{*}{2000} & 2.311 & 98.6 & 0.033 & 1.4 & - & - & 2.345 \\
\hline & \multicolumn{7}{|c|}{ Education of household head (3) } \\
\hline 1989 & 1.012 & 95.2 & 0.070 & 6.6 & -0.020 & -1.8 & 1.063 \\
\hline 1991 & 0.841 & 97.7 & 0.069 & 8.0 & -0.049 & -5.7 & 0.860 \\
\hline 1993 & 1.271 & 104.6 & 0.101 & 8.4 & -0.158 & -13.0 & 1.215 \\
\hline 1995 & 1.110 & 100.3 & 0.119 & 10.7 & -0.122 & -11.1 & 1.106 \\
\hline 1998 & 1.986 & 97.2 & 0.118 & 5.8 & -0.060 & -2.9 & 2.044 \\
\hline 2000 & 2.228 & 95.0 & 0.117 & 5.0 & - & - & 2.345 \\
\hline
\end{tabular}


Table 8 (continued)

\begin{tabular}{|c|c|c|c|c|c|c|c|}
\hline \multirow[t]{2}{*}{ Year } & \multicolumn{2}{|c|}{$\begin{array}{l}\text { Within groups } \\
\text { at fixed weights }\end{array}$} & \multicolumn{2}{|c|}{$\begin{array}{l}\text { Between groups } \\
\text { at fixed weights }\end{array}$} & \multicolumn{2}{|c|}{$\begin{array}{l}\text { Group relative } \\
\text { size effect }\end{array}$} & \multirow[t]{2}{*}{ Total } \\
\hline & Value & Share & Value & Share & Value & Share & \\
\hline & \multicolumn{7}{|c|}{ Homeownership } \\
\hline 1989 & 1.041 & 97.9 & 0.060 & 5.7 & -0.038 & -3.6 & 1.063 \\
\hline 1991 & 0.810 & 94.1 & 0.068 & 8.0 & -0.018 & -2.1 & 0.860 \\
\hline 1993 & 1.188 & 97.8 & 0.086 & 7.1 & -0.060 & -5.0 & 1.215 \\
\hline 1995 & 1.047 & 94.7 & 0.092 & 8.3 & -0.033 & -3.0 & 1.106 \\
\hline 1998 & 1.994 & 97.5 & 0.082 & 4.0 & -0.032 & -1.6 & 2.044 \\
\hline \multirow[t]{2}{*}{2000} & 2.251 & 96.0 & 0.094 & 4.0 & - & - & 2.345 \\
\hline & \multicolumn{7}{|c|}{ Stock-holding (4) } \\
\hline 1989 & 1.423 & 133.8 & 0.100 & 9.4 & -0.460 & -43.3 & 1.063 \\
\hline 1991 & 1.010 & 117.3 & 0.082 & 9.5 & -0.231 & -26.8 & 0.860 \\
\hline 1993 & 1.457 & 119.9 & 0.129 & 10.6 & -0.371 & -30.6 & 1.215 \\
\hline 1995 & 1.261 & 114.0 & 0.138 & 12.4 & -0.292 & -26.4 & 1.106 \\
\hline 1998 & 2.008 & 98.2 & 0.182 & 8.9 & -0.146 & -7.1 & 2.044 \\
\hline 2000 & 2.207 & 94.1 & 0.138 & 5.9 & - & - & 2.345 \\
\hline
\end{tabular}

Source: our calculations on data from the SHIW-HA (Version 2.1). "Value" refers to the absolute contribution of the component to the total index; "share" refers to the percentage ratio of the same contribution to the total index. Figures may not add up to the total because of rounding. (1) The five areas of residence are: North-West, North-East, Centre, South, and Islands. (2) Household heads are grouped by age in twelve classes: under 26 years, from 26 to 30 and then nine other classes of 5 years each, 76 and over. (3) The five levels of education of household heads are none, elementary school, middle school, high school, and university degree. (4) Stockholding refers to the possession of private bonds, equities or mutual funds.

\section{CONCLUDING REMARKS}

This paper was concerned with the size distribution of household wealth in Italy. We assembled aggregate data to sketch the evolution of household portfolios over the last forty years and to provide a benchmark for the microeconomic evidence. This evidence was based on the Bank of Italy's Survey of Household Income and Wealth, a long-established sample survey which has gathered detailed and exhaustive information on the net worth of Italian households since 1987.

The limits of sample surveys for the study of wealth distribution are well-known, and have led some researchers to question their usefulness altogether. A more balanced view was taken by Atkinson and Harrison (1978) in their extensive investigation of the personal distribution of net worth in Britain:

"The experience to date suggests that sample surveys are unlikely by themselves to provide a fully satisfactory source of information about the size distribution of wealth as a whole. ... Sample surveys may be a valuable supplement to the estate data, throwing light on the wealth not covered by the estate returns; they may also provide useful information about the holdings of certain types of asset (e.g. consumer 
durables). But in our view they cannot provide an alternative to the estate method as a source of evidence about wealth-holding at the top of the scale." (pp. 274-5).

Nevertheless, sample surveys are the primary source for wealth distribution in countries like Canada and the United States. In both countries, the underrepresentation of the wealthiest is brought under control by oversampling high-income households.

Our SHIW data suffer from the problems of sample surveys and do not benefit from oversampling. In this paper, we documented nonresponse and misreporting in the SHIW and we observed large differences between the survey totals and the corresponding aggregate estimates. While being a matter of concern, these differences are not to be blamed wholly on the SHIW: they are due in part to irreconcilable diversities in classifications and definitions, in part to shortcomings in macro sources. We dealt with nonresponse, nonreporting and underreporting in our data by performing several statistical adjustments. We believe that the adjusted data paint a more realistic portrait of the distribution of household net worth in Italy, but we also reported the evidence for unadjusted data in order to show the robustness of our conclusions and their sensitivity to these statistical adjustments. In spite of the corrections, the results still reflect the imprecise representation of the upper tail of the wealth distribution, and we reiterate the warning to interpret them with caution.

On the substantive side, the main results presented in the paper are the following.

- The aggregate figures show that dwellings and more generally tangible assets are still the main component of household wealth. The share of total financial assets has fluctuated over the years, but has increased only modestly. The investment in risky assets grew considerably during the 1990s, in parallel with the stock market boom and the rapid privatization of state-owned corporations and public utilities. The portfolio composition has tilted again towards tangible assets in the last couple of years, with the fall in share prices and rise in house prices.

- According to the SHIW adjusted data, at the end of 2000 the average net worth of Italian households amounted to 270,000 euros. From 1989 to 2000, it grew in real terms by 2.7 percent each year, while real disposable income remained unchanged. During the same period, households of the elderly, the retired, and people living in the North experienced the highest increase in mean net worth.

- Asset holdings vary considerably across the wealth distribution. At the bottom, consumer durables account for the largest fraction of net worth. In middle classes a very high proportion is held in real estate, particularly the principal residence. Businesses and risky financial assets are most frequent among the richest. While the ownership of equities and 
mutual funds spread across all classes during the 1990s, their amount came to account for a large proportion of portfolios only among the very wealthy.

- The distribution of wealth is a lot more unequal than the distribution of income. In 2000 the Gini index was 0.61 for net worth, compared with 0.37 for disposable income; it was 0.60 for tangible assets, and a much higher 0.81 for financial assets.

- Wealth inequality declined from 1989 to 1991 and then rose considerably in the rest of the 1990s. The increase was driven by large gains at the very top of the distribution.

- Our decompositions of inequality indices show that a great deal of the widening of household wealth distribution was due to financial assets, which have both augmented their weight in portfolios and become more heavily concentrated. This evidence suggests that the stock market boom of the 1990s was an important factor behind the recent growth of wealth inequality.

How does Italian wealth distribution compare with that of other countries? Let us consider the United States, and in particular the evidence of the Survey of Consumer Finances (SCF) (Kennickell, Starr-McCluer, and Surette, 2000). On the basis of our adjusted data, in 1998 the mean Italian household was almost as rich as the mean U.S. household (274,200 vs. 282,500 U.S. dollars, at average market exchange rate), whereas the median household was twice as rich as its American counterpart (148,400 vs. 71,600 U.S. dollars). With unadjusted data, the mean household was poorer in Italy than in the United States by about a third, but the median household was still richer by almost 60 percent. These results are rather surprising especially in the light of the divergent performance of the two economies in the 1990s. Several factors can help to explain them. There are important differences in institutional settings, for instance in the role of private pensions, as well as in demography the average family size is 2.6 persons in the SCF and 2.8 in the adjusted SHIW, while the shares of household heads older than 54 are 34.2 and 43.1 percent, respectively. Moreover, the household saving rate has traditionally been far higher in Italy than in the United States, implying a stronger wealth accumulation even when American incomes grow faster. ${ }^{19}$ On the other hand, differences in statistical methodology and definitions are so large

\footnotetext{
${ }^{19}$ A simple back-of-the-envelope calculation shows that an economy with a constant saving rate of 16 percent and an annual real income growth of 1.3 percent accumulates in ten years 80 percent more than an economy where the saving rate equals 6 percent and income grows at 1.9 percent per year, assuming that the initial income of the first economy is 69 percent of the income of the second economy (these values are the actual per capita values in the 1990 s for Italy and the United States, respectively).
} 
that these figures can only be very rough approximations. At face value, however, these figures, and more generally all available evidence, seem to suggest that the distribution of household wealth is much narrower in Italy than in the United States. ${ }^{20}$ In-depth work to improve data comparability is necessary to ascertain whether these international differences are statistical artifacts, or true ones. This task is left for future research. ${ }^{21}$

\footnotetext{
${ }^{20}$ See Faiella and Neri (2004) for a direct comparison, and Wolff $(1998,2000)$ and Kennickell (2001) for further estimates for the United States. The problems of international comparisons of wealth inequality are discussed by Wolff (1991, 1996), Kessler and Wolff (1991) and Davies and Shorrocks (2000).

${ }^{21}$ This is the aim of the Luxembourg Wealth Study (LWS), an international cooperative project launched in 2003 to create from existing data a database on household net worth comparable cross-nationally. The LWS project has currently the support of Canada, Cyprus, Finland, Germany, Italy, Norway, Sweden, the United Kingdom, and the United States. For further information, see the website <www.lisproject.org/lws.htm>.
} 


\section{APPENDIX A: CONSTRUCTION OF AGGREGATE STATISTICS}

In this Appendix we describe sources and methodology underlying the aggregate FANA statistics examined in Section 2. We deal separately with durable goods, dwellings, and financial assets and liabilities. We report the reconstructed time series in Table A1 and the percentage composition of total household net worth in Table A2.

\section{Durable Consumer Goods}

Following Pagliano and Rossi (1992), the stock of durable goods is computed by applying the perpetual inventory method to reconstructed series for the expenditure at constant prices on four different categories of durables, assuming exponential depreciation and retirement of the goods after a fixed number of years (20 years for furniture and furnishings, and 10 years for household equipment, transport, and TV, HI-FI and computer equipment). As standard in national accounts, the current values of the stock are expressed at substitution prices by multiplying the series at constant prices by the deflator of the corresponding expenditure.

\section{Dwellings}

The stock of dwellings at constant prices for the years 1980-2001 is based on a series provided by the Italian statistical office (Istat) calculated as part of the estimation of the capital stock. It is brought back to 1965 by keeping constant the depreciation rate for 1981, i.e. the ratio of consumption of fixed capital in 1981 to net capital in 1980, both evaluated at constant prices. The series is then expressed at market prices, rather than substitution prices, by using the housing price series estimated by Muzzicato, Sabbatini and Zollino (2002) (MSZ). The MSZ price series is based on information assembled in a semiannual survey of real estate agents and refers to actual sales of houses recently built in provincial capital towns in the second semester of each year. The price for the whole stock of houses is derived by scaling down this series by 0.73 , or the ratio of the average value per square meter for all houses to the corresponding value for houses recently built in provincial capitals as measured in the SHIW for 1993. The benchmark value of the stock of dwellings in 1991 is obtained by multiplying this adjusted price by the total area of Italian dwellings as registered in the Census. Figures for other years are derived by adjusting the 1991 value for the variations in both the real stock of dwellings and the adjusted MSZ price index. Finally, we assume that throughout the period under consideration households owned a fraction of total 
dwellings (occupied and unoccupied) equal to 91 percent, which is the value found in both the 1981 and 1991 Censuses.

\section{Financial Assets And Liabilities}

The Bank of Italy started to publish the Financial Accounts in its Annual Report for 1964. Here, we use the tables compiled by Cotula and Caron (1971) for the period 1965-1970 and by Marotta (1988) for the period 1975-1986, while we derive the data for 1971-74 and 198788 from the Annual Reports of the Bank of Italy. For the years from 1989 to 2002 we rely on the Financial Accounts database available at the Economic Research Department of the Bank of Italy (as of 19 June 2003). The access to this internal source allows us to produce figures for the entire period for consumer households alone, i.e. the sub-sector excluding unincorporated enterprises. (The publication of separate accounts for the two sub-sectors comprising the household sector has been suspended since the adoption of the new system of national accounts, ESA 1995.) These unpublished figures are preliminary and subject to revision.

The data assembled contain many discontinuities brought about by methodological revisions, use of better sources, or the appearance of new financial instruments. A major break occurs in 1989 and coincides with the first release of quarterly series. These discontinuities are not corrected except in one case. Following the adoption of ESA 1995, the comparison of new figures with earlier ones shows, in 1995-97, an upward revision of transaction and savings accounts by 13 percent and a downward revision of equities by an average 36 percent. Both variations were generated by the use of more comprehensive sources on the banking system and unlisted companies, respectively. As these revisions appear to have affected mostly levels rather than dynamics, we rescale values prior to 1995 by the ratio between new and old figures as recorded in 1995. This rescaling extends back to 1965 for transaction and savings accounts and to 1989 for equities.

Transaction and savings accounts include bank accounts, postal accounts and deposits at special credit institutions (the separation between banks and special credit institutions was abolished in 1993), and from 1989 onwards repurchase agreements. Long-term government bonds include those issued by local governments and public utilities. Other long-term domestic bonds comprise those issued by private enterprises and special credit institutions. Equities refer only to Italian stocks and include the shares of listed and unlisted incorporated businesses and the net capital of unincorporated banks not owned by the state; shares of unincorporated businesses are excluded. Foreign assets include short- and long-term bonds, 
equities, shares of mutual funds and other credits: the actual coverage of different assets may vary as a consequence of the controls on capital outflows in force for many years until the late 1980s. Insurance technical reserves also cover pension funds. Other assets include bank acceptances. Debts comprise all short- and long-term liabilities including loans by special credit institutions, mortgages by insurance companies and pensions funds, consumer credits by non-bank institutions and unpaid debts. 







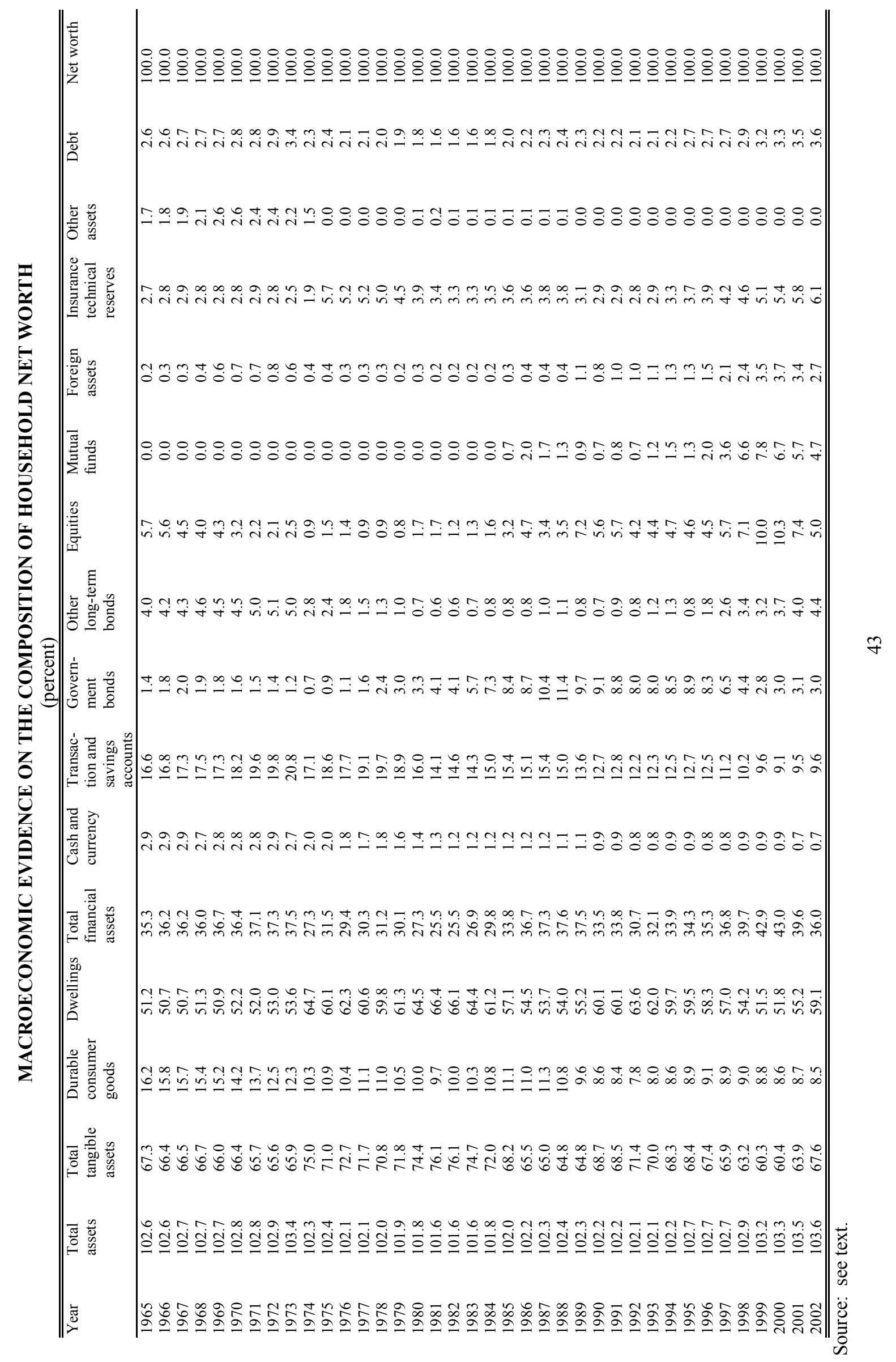




\section{APPENDIX B: ADJUSTMENT PROCEDURES}

\section{Adjustment For Non response}

Nonresponse is a problem in statistical surveys whenever it leads to samples where the less cooperative segments of the population are underrepresented, thus generating biased estimates (Cohen and Carlson, 1995). To limit these potentially distorting effects in the SHIW, particular attention is devoted in the fieldwork to elicit households' co-operation, although no money compensation is envisaged. When processing the data, the sample is post-stratified on the basis of certain characteristics of the household head (sex, age, and work status) to align the sampling distribution with distributions derived from external sources like the Census or the labor force survey. Post-stratification permits correction for those differences in the households' propensity to participate which are ascribable to the characteristics considered in the post-stratification (e.g. Madow, Nisselson, and Olkin, 1983). However, standard post-stratification techniques cannot fully compensate for the bias induced by the lower propensity of richer households to take part in sample surveys, as wealth is typically not an available characteristic (Cannari and D'Alessio, 1992; D'Alessio and Faiella, 2002).

D'Alessio and Faiella (2002) examine a few alternative models to estimate the ex-ante probability of participating in the SHIW and find that they tend to produce similar results. The model that can be most easily replicated for the various surveys exploits the information on the number of contacts needed to obtain an interview. More precisely, it assumes that the households requiring at least two visits before conceding the interview are representative of nonresponding units as a whole. Under this assumption, the unconditional probability of responding in the survey is taken to coincide with the estimated probability of responding at the first visit. Once such probability $p_{r i}$ is available, an unbiased estimator of the population mean is (e.g. Little and Rubin, 1987):

$$
\bar{y}=\sum_{i=1}^{R}\left(\frac{1}{p_{i} p_{r i}}\right) y_{i} / \sum_{i=1}^{R}\left(\frac{1}{p_{i} p_{r i}}\right),
$$

where $p_{i}$ is the usual probability of selection and $R$ is the number of responding households.

To obtain unbiased estimates, we borrow the procedure proposed by D'Alessio and Faiella (2002) and adjust the sampling weights as in (B1). The estimate of a logistic model on 1998 data reported in Table B1 shows that the nonresponse probability rises with school attainment, household size, income, and wealth; it is higher in the North, and in smaller municipalities; it falls with the age of the household head up to the age of 60 and then it 
increases. These parameters are fitted to other surveys, after rescaling income and wealth by the ratio of each year average to the corresponding 1998 average, and calibrating the model intercept to allow for the different response rates in each survey. The adjusted sampling weights are finally post-stratified to reestablish the marginal distributions of components by sex, age group, type of job, geographical area, and demographic size of the municipality of residence, as registered in population and labor force statistics.

Table B1

ESTIMATED NONRESPONSE PROBABILITY, 1998

\begin{tabular}{|c|c|c|c|c|c|c|}
\hline$\overline{\text { Variable }}$ & $\begin{array}{l}\text { Parameter } \\
\text { estimate }\end{array}$ & $\begin{array}{l}\text { Standard } \\
\text { error }\end{array}$ & Wald $\chi^{2}$ & $\overline{P r}>\chi^{2}$ & $\begin{array}{l}\text { Standard } \\
\text { estimate }\end{array}$ & "Odds ratios \\
\hline Intercept & 0.317 & 0.383 & 0.682 & 0.409 & & \\
\hline Poorly educated & $-0.118^{*}$ & 0.064 & 3.422 & 0.064 & -0.031 & 0.889 \\
\hline Highly educated & $0.255^{* *}$ & 0.101 & 6.336 & 0.012 & 0.041 & 1.290 \\
\hline North & $0.604 * * *$ & 0.072 & 70.499 & 0.000 & 0.166 & 1.830 \\
\hline South & $0.278 * * *$ & 0.082 & 11.573 & 0.001 & 0.069 & 1.320 \\
\hline Small municipality & $0.628 * * *$ & 0.074 & 73.025 & 0.000 & 0.129 & 1.875 \\
\hline Age & $-0.081 * * *$ & 0.010 & 70.965 & 0.000 & -0.792 & 0.922 \\
\hline Age squared & $0.001 * * *$ & 0.000 & 64.666 & 0.000 & 0.769 & 1.001 \\
\hline Household size & $0.085 * * *$ & 0.024 & 12.722 & 0.000 & 0.060 & 1.089 \\
\hline Log of income & $0.123 * * *$ & 0.032 & 14.838 & 0.000 & 0.072 & 1.131 \\
\hline Log of real wealth & 0.004 & 0.006 & 0.452 & 0.502 & 0.010 & 1.004 \\
\hline Log of financial wealth & $0.022 * * *$ & 0.007 & 10.419 & 0.001 & 0.054 & 1.022 \\
\hline \multicolumn{7}{|c|}{ Model Fitting Information and Testing Global Null Hypothesis BETA=0 } \\
\hline Criterion & \multicolumn{2}{|c|}{ Intercept Only } & \multicolumn{2}{|c|}{ Intercept and covariates } & \multicolumn{2}{|c|}{$\chi^{2}$ for covariates } \\
\hline AIC & \multicolumn{2}{|l|}{$9,147.864$} & \multicolumn{2}{|c|}{$8,805.922$} & \multicolumn{2}{|l|}{-} \\
\hline $\mathrm{SC}$ & \multicolumn{2}{|l|}{$9,154.694$} & \multicolumn{2}{|c|}{$8,887.885$} & \multicolumn{2}{|l|}{-} \\
\hline-2 LOG L & \multicolumn{2}{|l|}{$9,145.864$} & \multicolumn{2}{|c|}{$8,781.922$} & \multicolumn{2}{|c|}{$\begin{array}{l}363.942 \text { with } 11 \mathrm{DF} \\
(p=0.0001)\end{array}$} \\
\hline Score & \multicolumn{2}{|l|}{-} & \multicolumn{2}{|l|}{-} & \multicolumn{2}{|c|}{$\begin{array}{l}353.943 \text { with } 11 \mathrm{DF} \\
(p=0.0001)\end{array}$} \\
\hline
\end{tabular}

Source: our calculations on data from the SHIW-HA (Version 2.1). ${ }^{*}$ Significant at a 10 percent confidence level; ** significant at a 5 percent confidence level; *** significant at a 1 percent confidence level.

\section{Adjustment For Nonreporting And Underreporting of Financial Assets}

The adjustment builds on a method originally proposed by Cannari et al. (1990) based on the integration of the SHIW data for 1987 with the micro-data from a survey carried out in the same year by Banca Nazionale del Lavoro (BNLS) on a sample of its customers. The BNLS was not representative of the Italian population, but had the advantage of providing more reliable information on interviewees' financial behavior, owing to the greater trust that customers are likely to place in their own bank. Indeed, after allowing for the different composition of the two samples, Cannari et al. (1990) found that SHIW figures fell short of the corresponding BNLS aggregates by about a half, underreporting being higher for the 
households of the elderly, the less educated, and the self-employed. As adjustment for underreporting proposed by Cannari et al. (1990) requires the availability of both the SHIW and the BNLS at the same time and no further BNLS has been carried out since 1987, we apply the updated and revised methodology developed by Cannari and D'Alessio (1993). The procedure works in three steps.

- Imputation of bank and postal deposits. Assuming that there are no households reporting an asset without holding it, the probability of holding an asset conditional on not declaring it, $P_{h / n d}$, can be computed on the basis of marginal probabilities as:

$$
P_{h / n d}=1-\left(1-P_{h}\right) /\left(1-P_{d}\right)
$$

where $P_{h}$ is the unconditional probability of holding an asset and $P_{d}$ the unconditional probability of declaring it. While $P_{d}$ can be estimated from the SHIW data as a function of household characteristics (such as the head's age and education, income, etc.), the estimate of $P_{h}$ has to rely on external information. Let the asset be a bank deposit. Suppose that the logarithm of the probability of declaring a bank deposit is proportional to the logarithm of the probability of holding it and is independent of household characteristics:

$$
\log P_{d}=k \log P_{h}
$$

(in so far as $P_{d} \leq 1$, (B3) implies that $P_{h} \leq 1$ as well). Suppose also that the ratio $P_{d} / P_{h}$, i.e. the probability of reporting bank deposits conditional to holding at least one account, is equal, on average, to the ratio of the survey-based total of bank accounts to the corresponding figure derived from the statistics on the banking system, $r$ :

$$
E\left(P_{d}\right) / E\left(P_{h}\right)=r
$$

where $E$ stands for expected value. Together (B3) and (B4) allows for the estimation of the parameter $k$, and then of the probability of holding bank deposits $P_{h}$. Equation (B2) is then used for imputation. This method has the desirable properties that $P_{d}$ is always less than $P_{h}$ and the two probabilities are positively correlated. As $P_{d}$ increases with income, the latter feature prevents the imputation of bank deposits to the poorest households in the sample. For lack of better information, this method, including the estimated value for $k$, is also applied to postal deposits.

- Imputation of financial assets, excluding bank and postal deposits. Under the assumption that they are not affected by nonreporting behavior, the BNLS data allow us to compute $P_{h}$ as a function of household characteristics. (B2) can be used to impute the holding of 
an asset to nonreporting households. The amounts are subsequently imputed using standard imputation techniques. They are obviously underreported to the same extent as non-imputed data.

- Adjustment for underreporting of financial assets. The logarithm of the true amount of financial assets $w_{i}$ is assumed to be a linear function of characteristics $x_{i}$ of household $i$ :

$$
\log w_{i}=b_{0}+x_{i} b+u_{i}
$$

As above, the BNLS data are supposed to be unaffected by underreporting and used to estimate (B5). Assuming that the true amount $w_{i}$ is underreported by a multiplicative factor related to household characteristics, the declared amount $w_{i}^{d}$ is equal to $e^{a_{0}+x_{i} a+v_{i}}$ times the true amount $w_{i}$. It follows that, after estimating the equation

$$
\log w_{i}^{d}=b_{0}^{d}+x_{i} b^{d}+u_{i}^{d}
$$

on the SHIW data, the true amount can be recovered as

$$
\hat{w}_{i}=e^{-\hat{a}_{0}-x_{i} \hat{a}} w_{i}^{d}=e^{\left(\hat{b}_{0}-\hat{b}_{0}^{d}\right)+x_{i}\left(\hat{b}-\hat{b}^{d}\right)} w_{i}^{d} .
$$

For further details and the full set of estimates see Cannari and D'Alessio (1993).

We use the estimates from 1987 data to correct for non and underreporting in subsequent years. Available data do not allow us to test the maintained assumption that households' reporting behavior has not varied over the period. It is reassuring, however, to note that the extent of interviewees' reticence in 1987 was not very different from that found by Ulizzi (1967) twenty years earlier (Cannari and D’Alessio, 1993, p. 400).

\section{Adjustment For Nonreporting of Dwellings}

We correct for the underreporting of dwellings caused by nonsampling errors by adapting a method discussed by Cannari and D'Alessio (1990). The empirical distribution of the number of houses recorded in the SHIW, excluding those where the household lives, is well approximated by a discrete Poisson distribution, identified by the parameter $\lambda_{d}(x)$, where $x$ is a vector of household characteristics (including sex, age and age squared of the household head, income, income squared, place of residence, municipality size, household size, homeownership, annual dummy). Lacking more precise information, we assume that all dwellings not used as principal residence are equally likely to be declared by the owners. The probability that one of these dwellings is declared in the SHIW can then be described by the binomial distribution 


$$
\operatorname{Pr}(D=d \mid S=s)=\left(\begin{array}{l}
s \\
d
\end{array}\right) p^{d}(1-p)^{(s-d)},
$$

where $s$ is the number of dwellings owned (excluding the household residence), $d \leq s$ is the number of those declared and $p$ is the proportion of these dwellings recorded in the SHIW. Equation (B8) implies that the probability distribution of houses actually owned (excluding the household residence) is the same as that of declared houses or, more precisely, it is a Poisson distribution with parameter $\lambda_{s}(x)=\lambda_{d}(x) / p$. By computing $\operatorname{Pr}(S=s \mid D=d)$, it is then possible to impute the ownership of nonreported dwellings. Characteristics and value are assigned by a hot-deck method controlling for geographical area and income brackets. For each year, the proportion $p$ is computed as the ratio of the number of dwellings owned by the households (excluding the household residence) recorded in the SHIW, after the adjustment for nonresponse, to the corresponding "true" figure. The latter figure is taken from the Census for 1991 (so that $p=0.383$; see Table 1); it is extrapolated on the basis of the average rate of growth of the number of family-owned dwellings as recorded in the Censuses of 1981 and 1991 for other years.

As in the SHIW respondents are requested to complete a separate sheet for each dwelling they own, failing to report certain assets is a way of reducing the answering burden. The method just described - that can be seen as the equivalent of a proportional adjustment rule for a discrete variable - can account for such nonreporting behavior, but relies on the crucial assumption that the degree of reticence of respondents is constant across socioeconomic characteristics and, in particular, wealth classes. Some indirect evidence that the adjustment works satisfactorily is provided by the similarity of the distributions of rental incomes in the adjusted SHIW data and in tax returns, although it may still slightly underestimate the underreporting of the richest households. 


\section{REFERENCES}

Ando, A., L. Guiso, and I. Visco, eds. 1994. Saving and the Accumulation of Wealth. Essays on Italian Households and Government Saving Behaviour. Cambridge: Cambridge University Press.

Antoniewicz, R. L. 2000. "A Comparison of the Household Sector from the Flow of Funds Accounts and the Survey of Consumer Finances." Federal Reserve Board of Governors, Mimeo.

Atkinson, A. B., and A. J. Harrison. 1978. Distribution of Personal Wealth in Britain. Cambridge: Cambridge University Press.

Avery, R. B., G. E. Elliehausen, and A. B. Kennickell. 1988. "Measuring Wealth with Survey Data: An Evaluation of the 1983 Survey of Consumer Finances." Review of Income and Wealth 34: 339-369.

Banca d'Italia. 1986. "La Ricchezza Delle Famiglie in Italia (1975-1985)." Bollettino Economico 7: 11*-23*.

Banca d'Italia. 2000. "Italian Household Budgets in 1998." In G. D'Alessio and I. Faiella, eds., Supplements to the Statistical Bulletin 10 (22): April.

Banca d'Italia. 2002a. "Italian Household Budgets in 2000." In G. D'Alessio and I. Faiella, eds., Supplements to the Statistical Bulletin 12 (6): January.

Banca d'Italia. 2002b. I conti finanziari dell'Italia. Rome: Banca d'Italia.

Brandolini, A. 1999. "The Distribution of Personal Income in Post-War Italy: Source Description, Data Quality, and the Time Pattern of Income Inequality." Giornale degli Economisti e Annali di Economia 58: 183-239.

Brandolini, A., and L. Cannari. 1994. "Methodological Appendix: The Bank of Italy's Survey of Household Income and Wealth." In Ando, Guiso and Visco, eds. (1994): 369-386.

Brandolini, A., and G. D'Alessio. 2003. "Household Structure and Income Inequality in Italy. A Comparative European Perspective.” In D. Del Boca and M. Repetto-Alaia eds., Women's Work, the Family and Social Policy. Focus on Italy in a European Perspective: 148-191. New York, N.Y.: Lang.

Cannari, L., and G. D'Alessio. 1990. "Housing Assets in the Bank of Italy's Survey of Household Income and Wealth." In C. Dagum and M. Zenga, eds., Income and Wealth Distribution, Inequality and Poverty: 326-334. Berlin: Springer-Verlag.

Cannari, L., and G. D’Alessio. 1992. "Mancate Interviste e Distorsione Degli Stimatori." Banca d'Italia, Temi di discussione, No. 172, June.

Cannari, L., and G. D'Alessio. 1993. "Nonreporting and Underreporting Behavior in the Bank of Italy's Survey of Household Income and Wealth." In Proceedings of the ISI 49th Session: 395-412. Florence: ISI. 
Cannari, L., and G. D’Alessio. 1994. "Composizione e Distribuzione Della Ricchezza Delle Famiglie.” In N. Rossi, ed., La transizione equa, 1992-1993. Secondo rapporto CNEL sulla distribuzione e redistribuzione del reddito in Italia: 245-277. Bologna: Il Mulino.

Cannari, L., and G. D’Alessio. 2002. "La Distribuzione Del Reddito e Della Ricchezza Nelle Regioni Italiane.” Rivista economica del Mezzogiorno 16: 809-847.

Cannari, L., and R. Violi. 1995. "Reporting Behaviour in the Bank of Italy's Survey of Italian Household Income and Wealth.” In C. Dagum and A. Lemmi, eds., Research on Economic Inequality 6: 117-130. Greenwich: JAI Press.

Cannari, L., G. D’Alessio, and A. Venturini. 2003. "La ricchezza delle famiglie nelle regioni italiane." Rivista economica del Mezzogiorno 27: 47-85.

Cannari, L., G. D’Alessio, G. Raimondi, and A. I. Rinaldi. 1990. "Le attività finanziarie delle famiglie italiane." Banca d'Italia, Temi di discussione, No. 135, July.

Casolaro, L., L. Gambacorta, and G. Gobbi. 2004. "I prestiti bancari per l'acquisto di abitazioni in Italia e nell'area dell'euro." Quaderni di economia immobiliare, 2, No. 2, pp. 24-39.

Casolaro, L., L. Gambacorta, and L. Guiso. 2004. "Regulation, Formal and Informal Enforcement and the Development of the Household Loan Market. Lessons from Italy." In G. Bertola, C. Grant and R. Disney, eds., The Economics of Consumer Credit: European Experience and Lessons from the U.S., forthcoming. Cambridge: MIT Press.

Cohen, S. B., and B. L. Carlson. 1995. "Characteristics of Reluctant Respondents in the National Medical Expenditure Survey." Journal of Economic and Social Measurement 21: 269-296.

Cotula, F., and M. Caron. 1971. "I conti finanziari dell'Italia. Dimensioni e struttura della ricchezza e del risparmio finanziario dell'economia." Bollettino della Banca d'Italia, 26 (6): 837-919.

Cowell, F. A. 1980. "On the Structure of Additive Inequality Measures." Review of Economic Studies 47: 521-531.

Cowell, F. A. 1989. "Sampling Variance and Decomposable Inequality Measures." Journal of Econometrics 42: 27-41.

Curtin, R. T., F. T. Juster, and J. N. Morgan. 1989. "Survey Estimates of Wealth: An Assessment of Quality." In R. E. Lipsey and H. Stone Tice, eds., The Measurement of Saving, Investment and Wealth: 473-548. Chicago: University of Chicago Press.

D'Alessio, G., and I. Faiella. 2002. 'Nonresponse Behaviour in the Bank of Italy's Survey of Household Income and Wealth." Banca d'Italia, Temi di discussione, No. 462, December.

Davies, J. B., and A. F. Shorrocks. 2000. "The Distribution of Wealth." In A. B. Atkinson and F. Bourguignon, eds., Handbook of Income Distribution 1: 605-675. Amsterdam: North-Holland. 
Di Addario, S. 2002. "Italian Household Tenure Choices and Housing Demand." Banca d'Italia, Mimeo.

Fabbri, D., and M. Padula. 2004. "Does Poor Legal Enforcement Make Households CreditConstrained?" Journal of Banking and Finance 28: 2369-2397.

Faiella, I., and A. Neri. 2004. "La ricchezza delle famiglie italiane e americane." Banca d'Italia, Temi di discussione, No. 501, June.

Forbes Magazine. 2002. "The World's Richest People," Issue 03.18.2002. Available at: $<$ www.forbes.com/billionaires $>$.

Goldsmith, R. W., and S. Zecchini. 1999. "The National Balance Sheet of Italy (18611973)" Rivista di storia economica 15 (new series): 3-19.

Guiso, L., and T. Jappelli. 1991. "Intergenerational Transfers and Capital Market Imperfections. Evidence from an Italian Cross-Section." European Economic Review 35: 103-120. Also in Ando, Guiso and Visco, eds. 1994: 330-348.

Guiso, L., and T. Jappelli. 2002. "Household Portfolios in Italy." In L. Guiso, M. Haliassos and T. Jappelli, eds., Household Portfolios. 251-287. Cambridge, Mass.: MIT Press.

Guiso, L., T. Jappelli and D. Terlizzese. 1994. "Why Is Italy's Saving Rate So High?” In Ando, Guiso and Visco, eds. (1994): 23-69.

Hayashi, F., A. Ando, and R. Ferris. 1988. "Life Cycle and Bequest Savings." Journal of the Japanese and International Economies 2: 450-491.

Inter-Secretariat Working Group on National Accounts. 1993. System of National Accounts, 1993. Brussels-Luxembourg, New York, Paris, Washington, D.C.: Commission of the European Communities-Eurostat, International Monetary Fund, Organisation for Economic Co-operation and Development, United Nations, World Bank.

Istat. 1995. $13^{\circ}$ Censimento generale della popolazione e delle abitazioni, 20 ottobre 1991. Popolazione e Abitazioni. Rome: Istat.

Jäntti, M. 2002. "Trends in the Distribution of Income and Wealth - Finland 1987-1998." Paper presented at the 27th IARIW General Conference, 18-24 August, Djurhamn, Sweden.

Jappelli, T., and L. Pistaferri. 2000. "The Dynamics of Household Wealth Accumulation in Italy." Fiscal Studies 21: 269-295.

Juster, F. T., and K. A. Kuester. 1991. "Differences in the Measurement of Wealth, Wealth Inequality and Wealth Composition Obtained from Alternative U.S. Wealth Surveys.” Review of Income and Wealth 37: 33-62.

Kennickell, A. B. 2000. "Asymmetric Information, Interviewer Behavior, and Unit Nonresponse." Board of Governors of the Federal Reserve System, Mimeo.

Kennickell, A. B. 2001. "An Examination of Changes in the Distribution of Wealth from 1989 to 1998: Evidence from the Survey of Consumer Finances.” Board of Governors of the Federal Reserve System, Mimeo. 
Kennickell, A. B., M. Starr-McCluer, and B. J. Surette. 2000. "Recent Changes in U.S. Family Finances: Results from the 1998 Survey of Consumer Finances." Federal Reserve Bulletin 90: 1-29.

Kessler, D., and E. N. Wolff. 1991. "A Comparative Analysis of Household Wealth Patterns in France and the Unites States." Review of Income and Wealth 37: 249-266.

Klevmarken, N. A. 2001. “On the Wealth Dynamics of Swedish Families 1984-1998.” Paper presented at the 21st Arne Ryde Symposium on "Non-Human Wealth and Capital Accumulation," 23-25 August, Lund, Sweden. Forthcoming in Review of Income and Wealth.

Little, R. J. A., and D. B. Rubin. 1987. Statistical Analysis with Missing Data. New York: Wiley \& Sons.

Madow, W. G., H. Nisselson, and I. Olkin. 1983. Incomplete Data in Sample Surveys. Report and Case Studies 1: New York: Academic Press.

Magnani, M. 1997. "La ricchezza finanziaria delle famiglie e la bilancia dei pagamenti di parte corrente Nord-Sud (1970-92).” Rivista economica del Mezzogiorn 11: 29-68.

Magri, S. 2002. "Italian Households' Debt: Determinants of Demand and Supply.” Banca d'Italia, Temi di discussione No. 454, October.

Marotta, G. 1988. "Gli stati patrimoniali dell'operatore famiglie in Italia, 1975-1986." Notiziario economico bresciano, pp. 20-30.

Morissette, R., X. Zhang, and M. Drolet. 2002. "The Evolution of Wealth Inequality in Canada, 1984-1999." Statistics Canada, Analytical Studies Branch, Research Paper, No. 187, February.

Muzzicato, S., R. Sabbatini, and F. Zollino. 2002. "I prezzi delle abitazioni in Italia: una rassegna di temi metodologici e la costruzione di un nuovo indice." Banca d'Italia, Mimeo.

Oja, G. 1986. "The Wealth of Canadians: A Comparison of Survey of Consumer Finances with National Balance Sheet Estimates." Statistics Canada, Labour and Household Surveys Analysis Division, Staff Reports, December.

Pagan, A., and A. Ullah. 1999. Nonparametric Econometrics. Cambridge: Cambridge University Press.

Pagliano, P., and N. Rossi. 1992. "The Italian Saving Rate: 1951 to 1990 Estimates." In G. Marotta, P. Pagliano and N. Rossi, Income and Saving in Italy: a Reconstruction, Banca d'Italia, Temi di discussione, No. 169, June.

Paiella, M. 2002, "Demand for Housing, Saving Behavior and Wealth Allocation." Banca d'Italia, Mimeo.

Paiella, M. 2004. "Does Wealth Affect Consumption? Evidence for Italy." Banca d'Italia, Temi di discussione, No. 510, July. 
Pantaleoni, M. 1890. "Dell'ammontare probabile della ricchezza privata in Italia dal 1872 al 1889." Giornale degli economisti 1 (2nd series): 139-176.

Pyatt, G., C.-N. Chen, and J. Fei. 1980. "The Distribution of Income by Factor Components." Quarterly Journal of Economics 95: 451-473.

Shorrocks, A. F. 1975. "The Age-Wealth Relationship: A Cross-Section and Cohort Analysis." Review of Economics and Statistics 57: 155-163.

Shorrocks, A. F. 1980. "The Class of Additively Decomposable Inequality Measures." Econometrica 48: 613-625.

Shorrocks, A. F. 1983. "The Impact of Income Components on the Distribution of Family Incomes." Quarterly Journal of Economics 98: 311-326.

Statistics Canada. 1979. Evaluation of Data on Family Assets and Debts, 1977. Ottawa: Statistics Canada.

Tresoldi, C., and I. Visco. 1975. "Un tentativo di stima della ricchezza delle famiglie (19631973)." Rivista di diritto finanziario e scienza delle finanze 34: 516-524.

Ulizzi, A. 1967. "La reticenza degli intervistati nella rilevazione campionaria dei titoli." Banca d'Italia, Internal Report.

Wolff, E. N. 1991. "The Distribution of Household Wealth: Methodological Issues, Time Trends, and Cross-Sectional Comparisons." In L. Osberg, ed., Economic Inequality and Poverty. International Perspectives: 92-133. New York: Sharpe.

Wolff, E. N. 1996. "International Comparisons of Wealth Inequality." Review of Income and Wealth 42: 433-451.

Wolff, E. N. 1998. "Recent Trends in the Size Distribution of Household Wealth." Journal of Economic Perspectives 12: 131-150.

Wolff, E. N. 2000. "Recent Trends in Wealth Ownership, 1983-1998." Working Paper, No. 300, April. Annandale-on-Hudson, N.Y.: The Levy Economics Institute.

Zamagni, V. 1980. "The Rich in a Late Industrialiser: The Case of Italy, 1800-1945." In W. D. Rubinstein, ed., Wealth and the Wealthy in the Modern World: 122-166. London: Croom Helm. 